\title{
OBSERVAÇŌES GERAIS SOBRE OS GRANDES TIPOS DE SOLO DO ESTADO DE SÃO PAULO
}

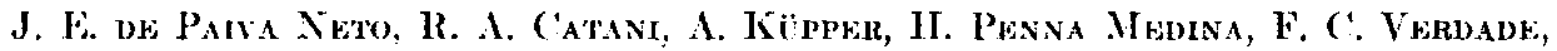
engenheiros agrônomos ; M. (iurmans, engenheiro de minas ; A. (: Nascimasto. engonheiro quimico; Serção de Agrogeologia, Instituto Agronômico de Campinas.

\section{1 - INTROI)UGÃ()}

As descriçôes gerais dos grandes tipos de solo contidas neste trabalho, baseiam-se em estudos de mais de 15 anos, compreendendo número superior a $80.000 \mathrm{~km}$ de excursão ; coleta de aproximadamente 4.000 amostras de rocha ; tomada de cêrca de 700 perfis de solo de 1,5 a 5,0 m de profundidade ; 20.000 amostras superficiais de solo e cêrca de 6.000 fotografias, documentando todos os acidentes responsáveis pela formação e pelo estado atual dos nossos solos. Tem sido usado na retirada de perfis e amostras superficiais, o sistema de Catena de Milne. O mapa da figura 1 indica os caminhamentos feitos pelos técnicos da Seç̧ão de Agrogeologia, o da figura 2 , a localização dos perfis e amostras superficiais de solo e o da figura 3 , a distribuição dos grandes tipos de solo.

A superfície estudada no Estado de São Paulo envolve cêrca de 24.700 .000 hectares e está situada entre as latitudes sul de $19^{\prime \prime} 50^{\prime}$ e $25^{\circ} 10^{\prime}$ c entre as longitudes (seg. Greenwich) de $44^{\prime \prime} 10^{\prime}$ e $53^{\circ} 10^{\prime}$. As altitudes variam entre 3 e $1700 \mathrm{~m}$ acima do nível do mar. As altitudes maiores encontramse no complexo cristalino (rochas predevonianas). Caracteriza-se o clima da legião do planalto do Estado por um período mais frio, comumente entre maio e julho, e que apre en⿳a uma tempe atura média de $14^{\circ}$ a $18^{\circ}$ $\mathrm{C}$, époea essa, no geral, sêca; outro pe íodo essencialmente quente, que vai de novembro a fevereiro, cuja temperatura média pode oscilar cntre $21^{\circ}$ e $2 \tilde{s}^{\circ} \mathrm{C}$ e, no geral, chuvoso. Nos seis meses restantes, o elima pode variar dentre os limites já mencionados, isto é, entre as duas estações extremas. A queda pluviométrica oscila, no litoral, entre 2.000 a $3.000 \mathrm{~mm}$ e no interior, entre 1.000 e $1.800 \mathrm{~mm}$.

Este trabalho tem por finalidade precípua, estudar e classificar essencialmente para fins agrícolas, os vários tipos de solos do Fistado, nos seus mais variados aspectos, tais eomo: grau de fertilidade, irrigação e drenagem, adubaçaso, etc.

\section{2 - SOL() MASSAPE-SALMOURĀO)}

Área -..- A área existente, já estudada, dêste tipo de solo, no Éstado, abrange cêrca de 5.900 .000 hectares, ou sejam $24,0 \%$ da área total.

Origem geológica - Provém êste grande tipo de solo de rochas do complexo cristalino, ou seja de rochas predevonianas. Os tipos prineipais 


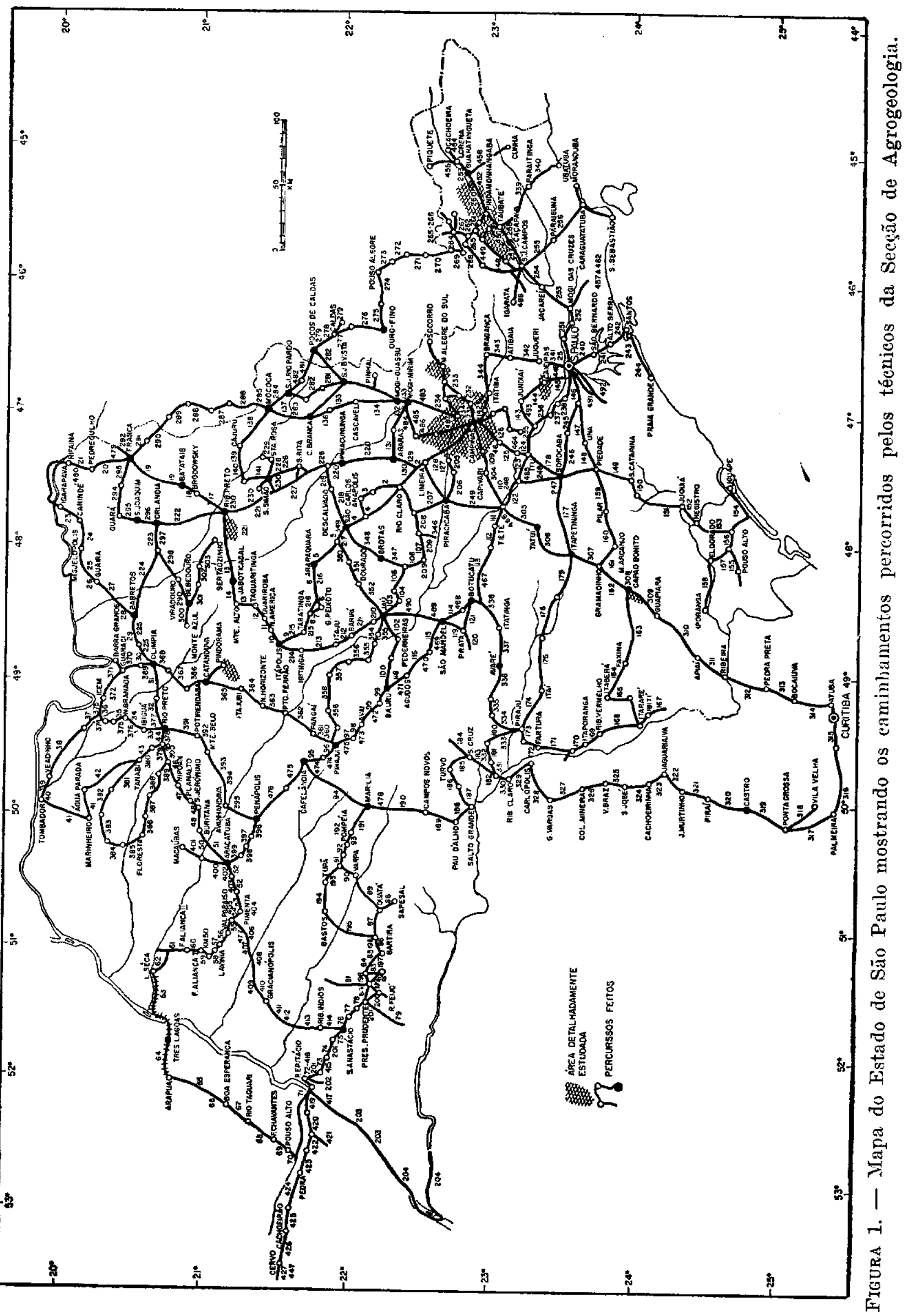



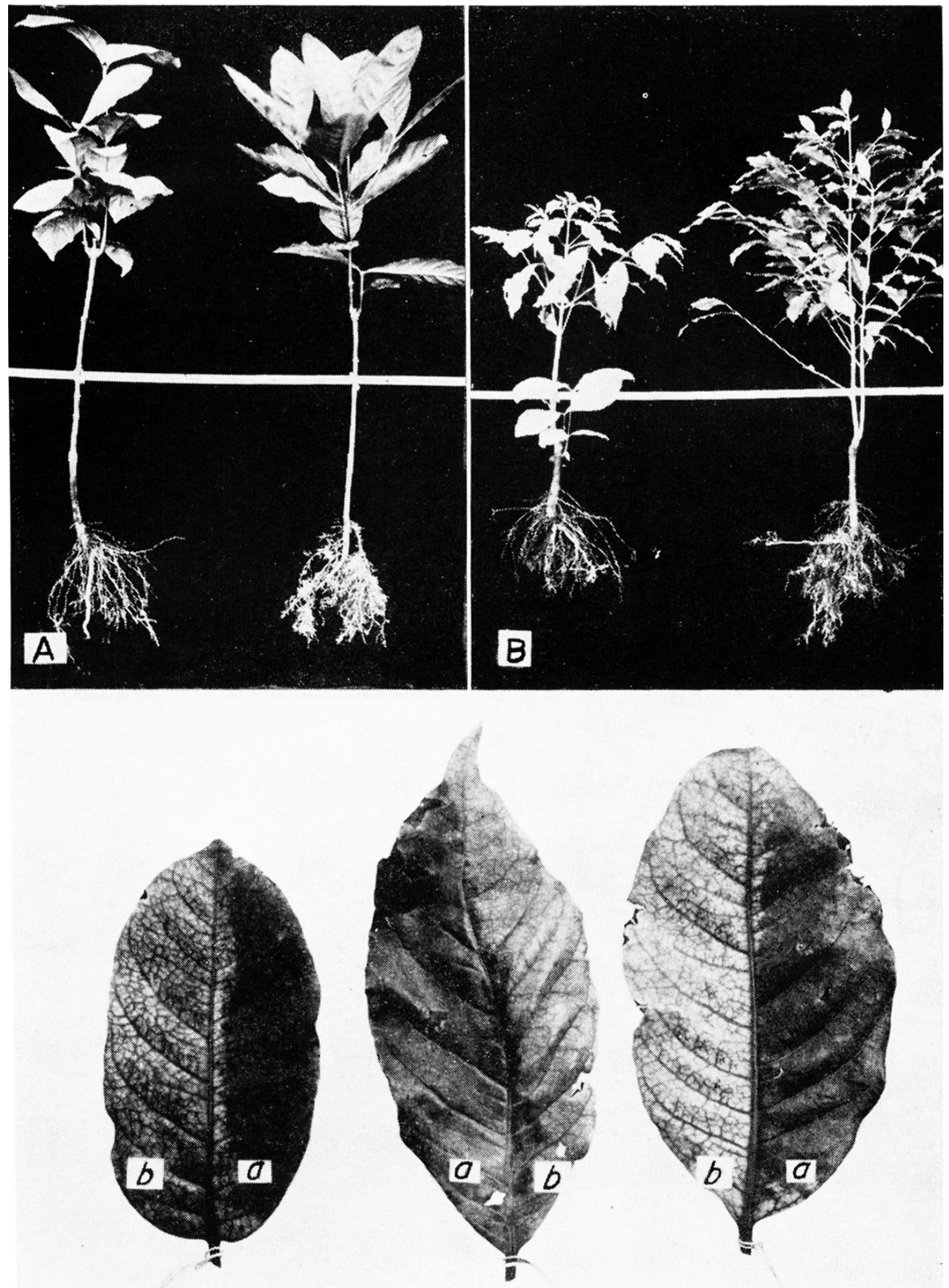

C

$A$ - Plantas de pé franco de ciafé excelsa: com clorose à esquerda, normal à direita. $B$ - Plantas de café arábica enxertadas sôbre cavalo de eafé excelsa: com elorose à esquerda, normal à direita. $C$ - Fôlhas de café excelsa com clorose: $a$ ) meiasfôlhas às quais foi aplicada uma soluçăo de sulfato de ferro a $1 \%$, por fricção, com auxílio de carborundo; $b$ ) meias-fôlhas tratadas por pulverização eom a mesma solueão. fotografadas 3 ก dise anós " twatrmant. 


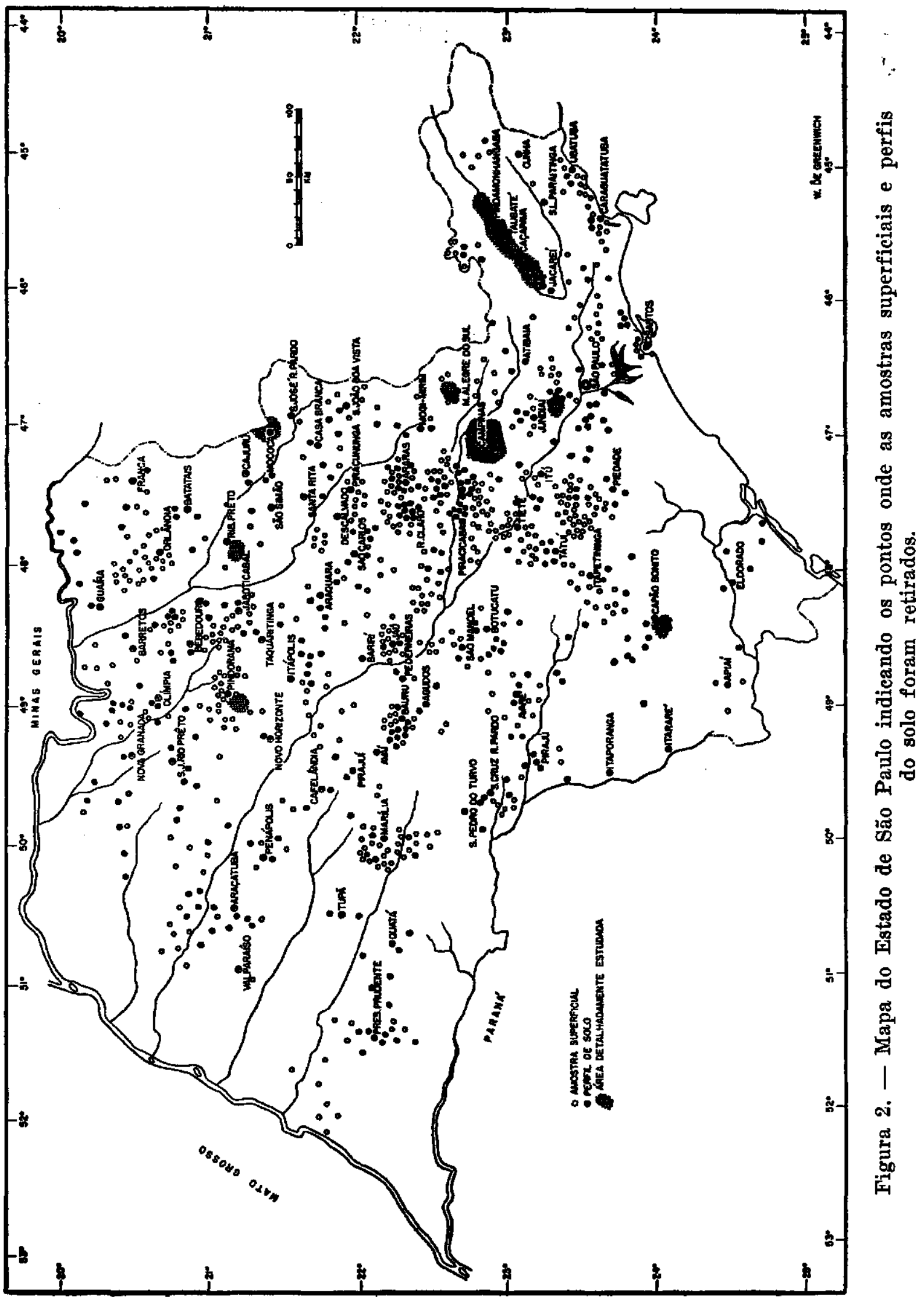


dessas rochas são: gnaisses, granitos, micaxistos, etc. As análises mineralógicas das frações "areia grossa e areia fina + limo", mostram grande riqueza em minerais primários, ricos em potássio e magnésio.

Topografia - São solos em geral de conformação muito acidentada ; a altitude pode variar entre 3 e $1.700 \mathrm{~m}$ acima do nível do mar.

Vegetação natural primária - São êstes solos, quando ainda virgens, cobertos por densas matas, apresentando, no geral, aspecto subhidrofílico. As estampas $1-A$ e $B, 2-A$ e $B$ e $3-A$ mostram vistas típicas da vegetação natural do solo Massapé-salmourão.

Perfil do solo - Deve-se dizer logo de início, que os solos tìpicamente massapés, são bastante argilosos, enquanto que os salmourões são mais pedregosos. A fração mais grossa é, no geral, constituída por fragmentos de quartzitos e cristais de feldspatos mais ou menos caolinizados. Os granitos são mais respunsáveis pelo subtipo salmourão, ao passo que os gnaisses e micaxistos são responsáveis pela origem do subtipo massapé.

Por enquanto, êsses dois subtipos só podem ser perimetrados conjuntamente. A razão reside, sobretudo, na não existência ainda de mapa petrográfico detalhado. A coloração dêstes solos é, em geral, amarelada ou avermelhada, podendo os primeiros $30 \mathrm{~cm}$ apresentar coloração parda ou acinzentada escura, devido ao maior ou menor teor em matéria orgânica. A coloração amarelada ou avermelhada se deve aos óxidos hidratados dc ferro.

Tanto no solo massapé-salmourão como nos outros tipos, não há, no geral, uma diferenciação pedológica intensa entre suas várias profundidades (0-1,5 m), mas, sim, variacão de ordem contínua.

Por esta lazão, no geral, os perfis são divididos da seguinte maneira : Primeira camada ou solo arável, com espessura de 0-35 ou $40 \mathrm{~cm}$; segunda. camada de 40-80 cm e terceira camada de 80-150 cm. Fm casos especiais, seguem-se ainda outras camadas, como sejam: de $150-200 ; 200-250 ; 250$ 300 e $300-500 \mathrm{~cm}$. Este esclarecimento serve para os demais tipos que serão descritos adiante.

Os solos pertencentes a êste grande tipo massapé-salmourão, הão, no geral, pouco permeáveis à água. Apesar de relativamente resistentes aos fenômenos da erosão, quando as rampas são muito fortes, sofrem, às vêzes, profundamente dêsse grande mal.

São solos ricos em elementos químicos no estado potencial e isto é claramente revelado pela análise química total, bem como pela análise mineralógica, que determina grande quantidade de micas, feldspatos, etc. Neste particular, êste solo se diferencia completamente dos demais, no Estado. A fração argila é constituída essencialmente por caolinita, podendo estar presente também hidrargilita (4).

A análise química média dos elementos trocáveis, assim como diversas constantes físicas importantes, podem ser consultadas nos quadros $1 \mathrm{e}$ 2. $(5,6)$. 

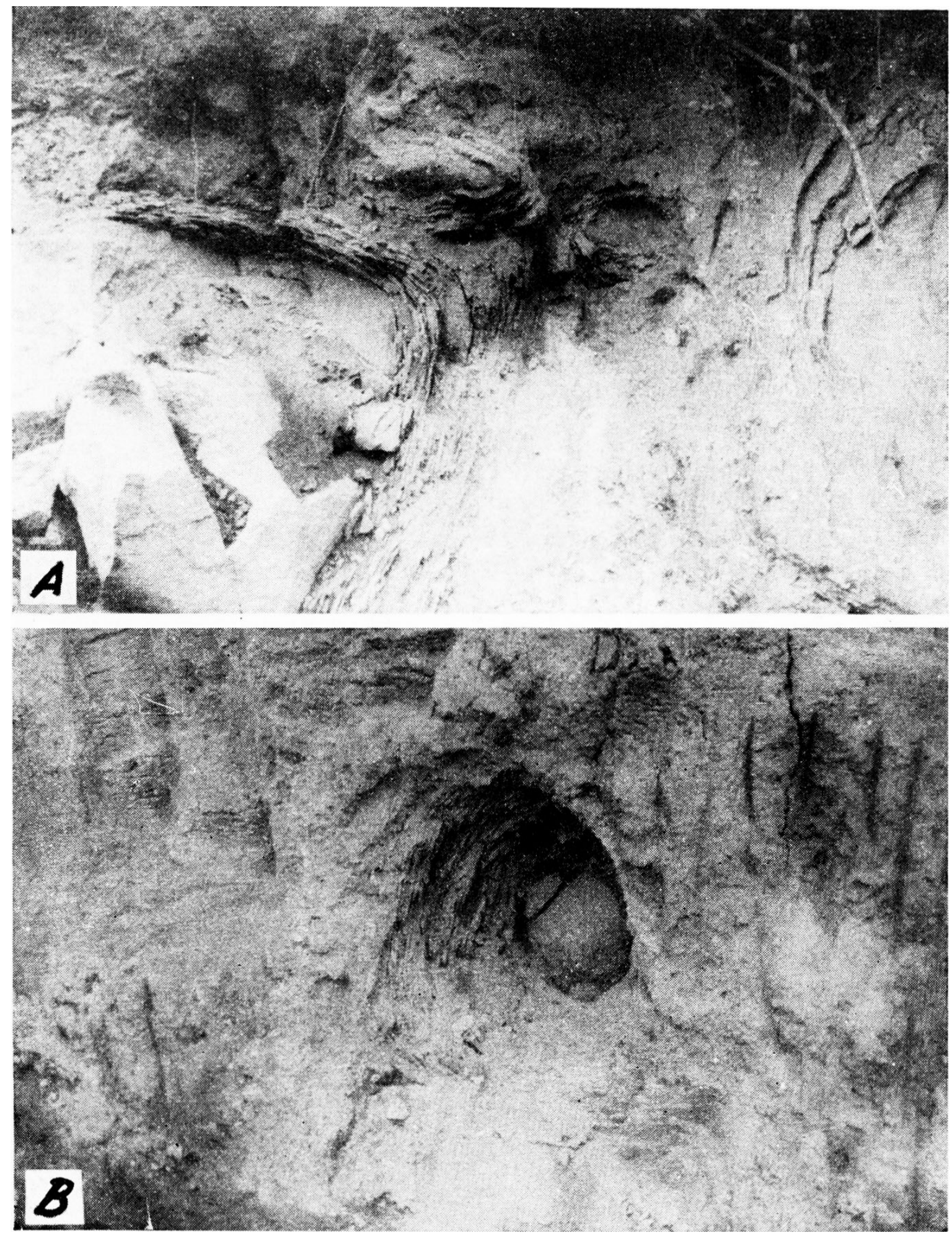

Massapé-Salmomño. $A$ a $B$-Localização: Entre Cunha e Guaratinguetá (Serma do Mar) (450 W. Gr. 2:3n S) ; altitude: $850 \mathrm{~m}$. Decomposição concêntrica do granito devido ao intemperismo local. 

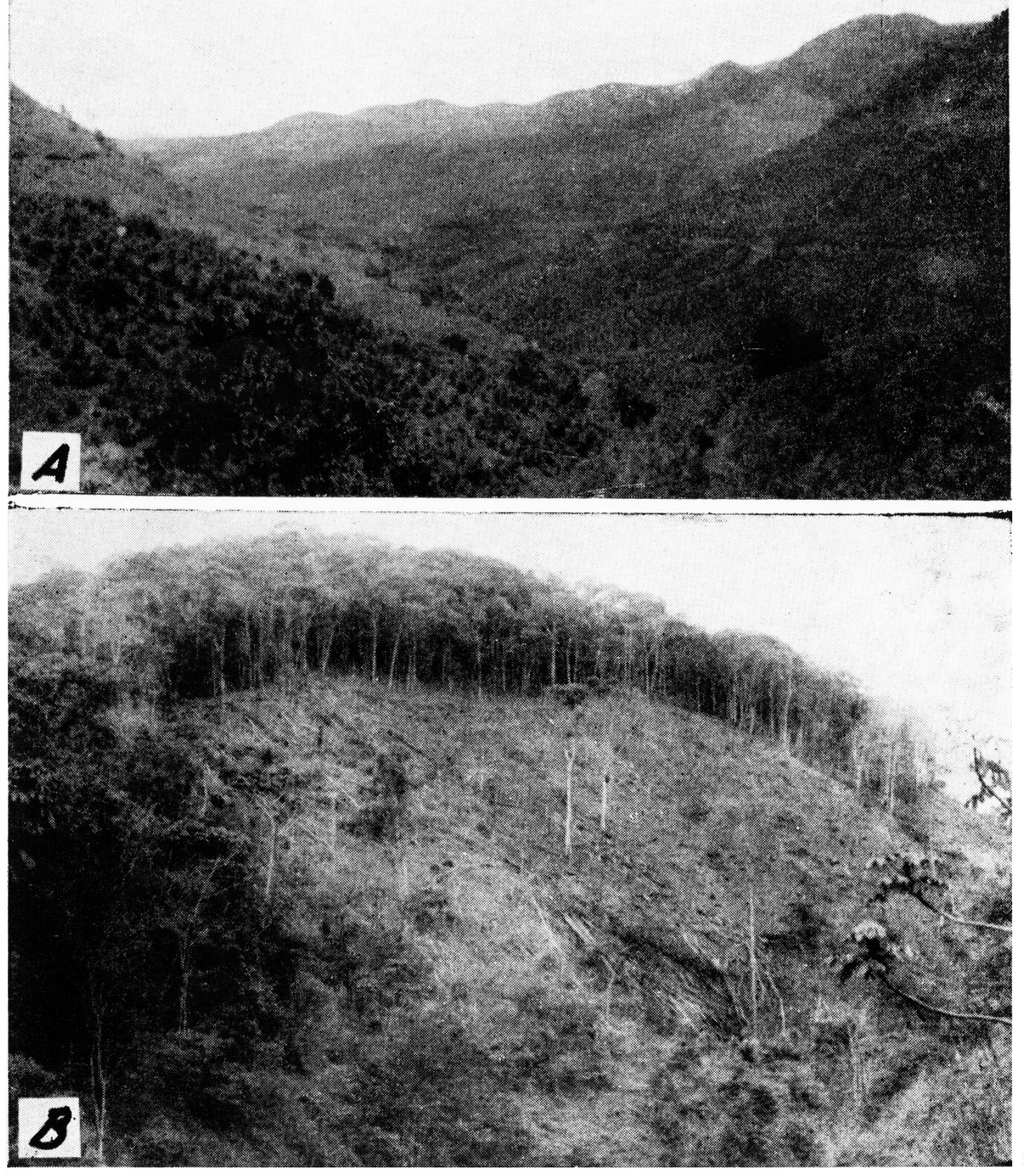

Salmourão-Massapé. A-Localizaçño: Fstação de Cascata (46040' W. Gr. 21vão' S); altitude: $1200 \mathrm{~m}$, mostrando a topografia acidentada dêsse tipo de solo, relativamente resistente à erosăo conforme se observa pelo cafèzal velho, ainda em produção. B-Localização: Fralda da Mantiqueira, em Pindamonhangaba (4503ら)' W. Gr. $22050^{\circ}$ S); altitude: 800 m. Observa-se a devastação da mata e predominância da rocha-mater Gnaiss. 
QUADro 1.-Caracteristicas físicas do solo do tipo massapé-salmourão. Dados gerais, análise mecânica total e fase líquida.

\begin{tabular}{|c|c|c|c|c|c|c|c|c|c|}
\hline \multirow{2}{*}{$\begin{array}{l}\text { ('amgula lo solo } \\
\text { (profundidade) }\end{array}$} & \multicolumn{2}{|c|}{ Massa especifica } & \multirow{2}{*}{$\begin{array}{l}\text { T'orosi- } \\
\text { dade } \\
\text { natural }\end{array}$} & \multicolumn{2}{|c|}{$\begin{array}{l}\text { Cor do solo } \\
\text { (Ostwald) }\end{array}$} & \multicolumn{2}{|c|}{$\begin{array}{c}\text { Areia grossa } \\
(2 \mathrm{a} 0,2 \mathrm{~mm})\end{array}$} & \multicolumn{2}{|c|}{$\begin{array}{c}\text { Limo } \\
(0,2 \text { a } 0,002 \mathrm{~mm})\end{array}$} \\
\hline & Real & Aparente & & Umido & Sêro & l'êso & Volume & Pёно & Volume \\
\hline & & & $\%$ & & & $\%$ & $\%$ & $\%$ & $\%$ \\
\hline $0-40 \mathrm{~cm}$ & 2,59 & 1,37 & 47,4 & $\lg 4-5$ & ie $4-5$ & 33,7 & 17,8 & 48,5 & 23,9 \\
\hline $40.80 \mathrm{~cm}$ & 2,62 & 1,45 & 44,0 & ng 5 & le 4-5 & 26,3 & 14,8 & 46,2 & 23,5 \\
\hline $80-150 \mathrm{~cm}$ & 2,65 & 1,42 & 45,6 & le 5 & ge 4 & 24,0 & 14,0 & 48,3 & 23,7 \\
\hline \multirow{2}{*}{$\begin{array}{l}\text { Camadu do solo } \\
\text { (profundidade) }\end{array}$} & \multicolumn{2}{|c|}{$(<0,002 \mathrm{~mm})$} & \multirow{2}{*}{$\begin{array}{l}\text { Indice } \\
\text { intern. } \\
\text { (Bujten- } \\
\text { zorg) }\end{array}$} & \multicolumn{2}{|c|}{$\begin{array}{l}\text { Umidade de } \\
\text { murchamento }\end{array}$} & \multicolumn{2}{|c|}{$\begin{array}{l}\text { Unidade equi- } \\
\text { valente }\end{array}$} & \multicolumn{2}{|c|}{$\begin{array}{c}\text { Agua capilar } \\
\text { máxima }\end{array}$} \\
\hline & P'éso & Volume & & Pêso & Volume & Peso & Volume & Pêso & Volumio \\
\hline & $\%$ & $\%$ & & $\%$ & $\%$ & $\%$ & $\%$ & $\%$ & $\%$ \\
\hline $0.40 \mathrm{~cm}$ & 17,8 & 9,4 & B. L. & 14,3 & 19,6 & 21,1 & 28,8 & 28,8 & 39,4 \\
\hline $40-80 \mathrm{~cm}$ & 27,5 & 14,9 & B. L. & 16,3 & 23,7 & 24,0 & 34,8 & 29,0 & 42,1 \\
\hline $80-150 \mathrm{om}$ & 27,7 & 14,8 & B. I. & 16,8 & 23,9 & 24,7 & 35,1 & 30,3 & 43,0 \\
\hline
\end{tabular}

\section{3 - SOLO DEVONIANO}

Área - Compreende êste tipo de solo cêrca de 100.000 hectares, ou, melhor, $0,4 \%$ da área total do Estado.

Topografia - Em geral é plana ou levemente ondulada. Podem, entretanto, aparecer desniveis repentinos e abruptos, superiores a $200 \mathrm{~m}$. As estampas 3-B e 4-A e $B$ mostram paisagens típicas dêstes solos. A altitude varia entre 800 e $1100 \mathrm{~m}$ acima do nível do mar.

Geologia - Provém êsse grande tipo de solo de arenitos do perísdo Devcniano, cuja textura pode variar bastante. A formação é rica em calcários. Essa variação de textura é devida, principalmente, ao maior ou menor tamanho dos grânulos de quartzo, bem como ao teor em argila. É bastante pobre em minerais importantes à alimentação das plantas. A análise petrográfica revela quase que exclusivamente quartzo, e a fração argila é constituída por caolinita. A estampa 3-B 4- $A$ e $B$ mostra os paredóes do arenito Devoniano, em parte influenciados pela erosão eólica.

Vegetação nativa - Consiste, no geral, em grandes planícies de pastagens. Encontramos nas leves depressర̃es molhos de pinheiros (Araucaria urasiliensis). Não há matas pròpriamente ditas ; no geral, pequenos capceirões. A barba de bode (Aristida pallens Cav.) é muito comum.

Perfil do solo - Os solos, no geral, são classificados como arenosos e barrentos, segundo a análise mecânica. A matéria orgânica está localizada 


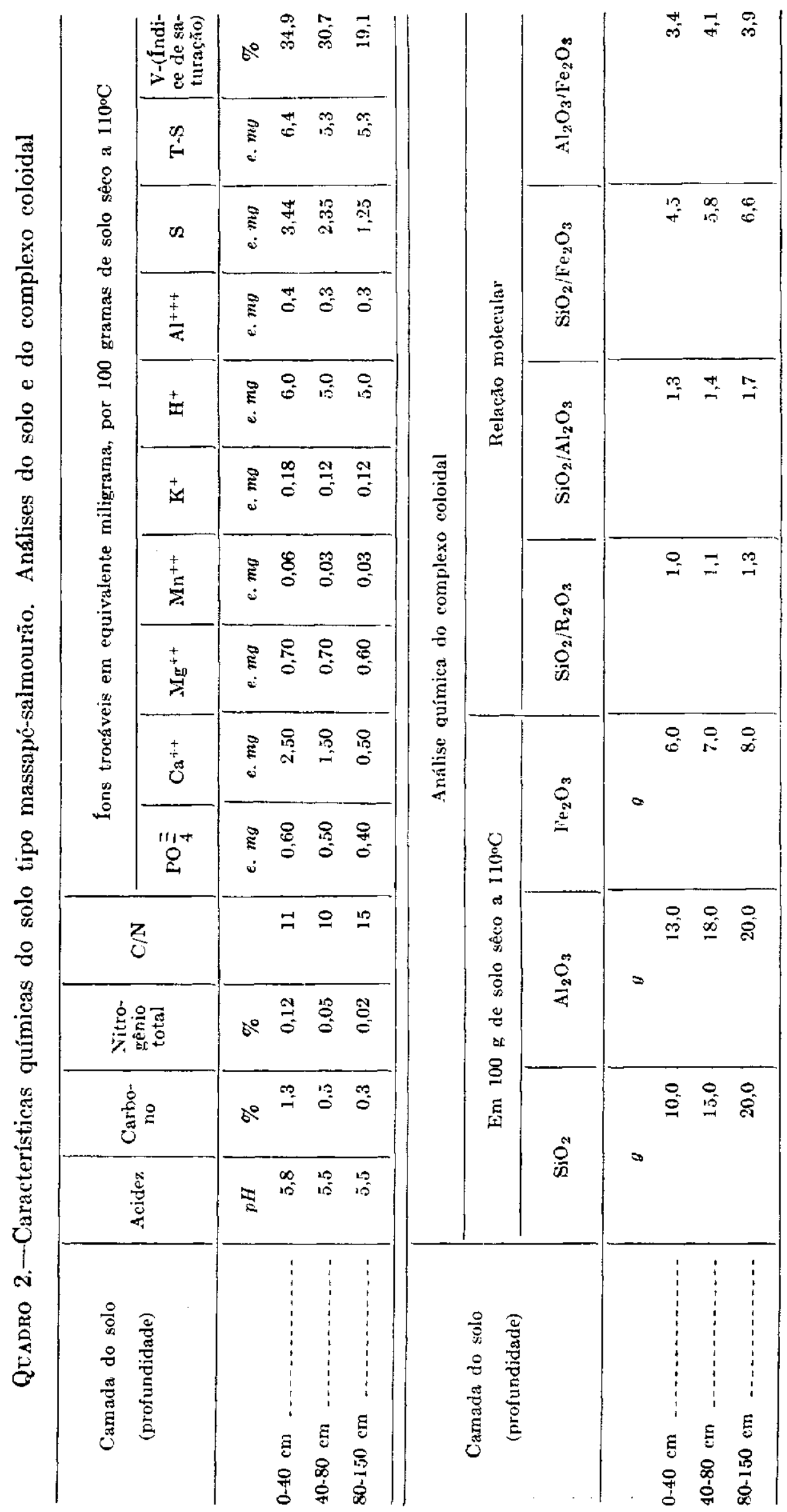




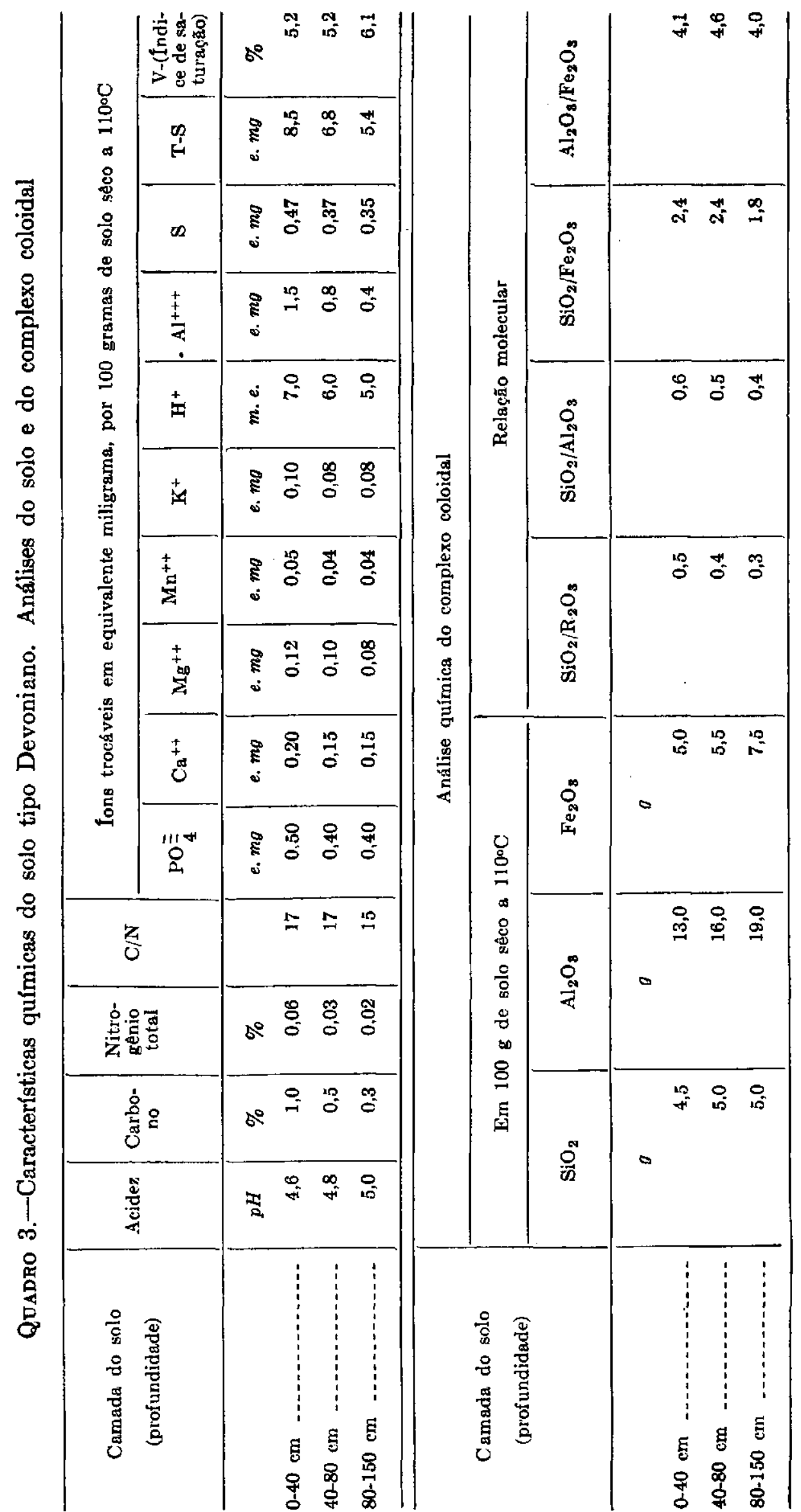


nos primeiros $30 \mathrm{~cm} \mathrm{e}$, em geral, em teor muito baixo (ver quadro 3). Abaixo dos 40-50 cm, começa, geralmente, o perfil a se adensar devido ao aumento de argila. A permeabilidade à água é pequena abaixo dos $40-50 \mathrm{~cm}$. A coloração é, comumente, clara ou acinzentada à superfície e amarela ou avermelhada nas camadas inferiores. São solos quimicamente pobres como podemos observar nas tabelas que seguem. Atualmente, são solos de pouco valor agrícola e também de menor importância em face de sua área relativamente pequena. Os dados químicos e físicos podem ser melhor observados nos quadros 3 e 4.

Culturas - A agricultura é diminula ; são áreas que, até o momento, fornecem essencialmente pastagens sof riveis.

Quadro 4.-Características físicas do solo tipo Glacial (arenoso). Dados gerais, análise mecânica total e fase líquida.

\begin{tabular}{|c|c|c|c|c|c|c|c|c|c|}
\hline \multirow{2}{*}{$\begin{array}{l}\text { (amada do solo } \\
\text { (profundidade) }\end{array}$} & \multicolumn{2}{|c|}{ Massa especifica } & \multirow{2}{*}{$\begin{array}{c}\text { Porosi- } \\
\text { dade } \\
\text { natural }\end{array}$} & \multicolumn{2}{|c|}{$\begin{array}{l}\text { (ór do solo } \\
\text { (O.t wald) }\end{array}$} & \multicolumn{2}{|c|}{$\begin{array}{l}\text { Arein grossa } \\
\text { (2 a } 0,2 \mathrm{~mm})\end{array}$} & \multicolumn{2}{|c|}{ 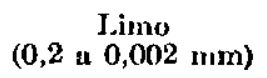 } \\
\hline & Real & Aparente: & & Émido & sereo & l'êso & Volume & Peso & Volume \\
\hline & & & $\%$ & & & $\%$ & $\%$ & $\%$ & $\%$ \\
\hline $0-40$ (m) & 2,59 & 1,33 & 48,6 & ng 5 & ng 4 & 52,6 & 27,8 & 38,7 & 19,8 \\
\hline $40-80 \mathrm{~cm} \quad \ldots \ldots$ & 2,63 & 1,31 & 50.3 & $l_{e} \quad \bar{j}$ & le 4 & 46,9 & $23, \pi$ & 36,2 & 17,9 \\
\hline $80-150 \mathrm{~cm}$ & 2,65 & 1,35 & 49,1 & ne: 5 & ne 4 & 34,1 & 16,8 & 38,7 & 20,1 \\
\hline \multirow{2}{*}{$\begin{array}{c}\text { (ambada do solo } \\
\text { (profundlidiate) }\end{array}$} & \multicolumn{2}{|c|}{$(<\underset{0,002 \mathrm{~mm}}{\text { Argila }})$} & \multirow{2}{*}{$\begin{array}{l}\text { fndice } \\
\text { intern. } \\
\text { (Buiten- } \\
\text { norg) }\end{array}$} & \multicolumn{2}{|c|}{$\begin{array}{l}\text { Umidade de } \\
\text { murchamento }\end{array}$} & \multicolumn{2}{|c|}{$\begin{array}{l}\text { Umidade equi- } \\
\text { valente }\end{array}$} & \multicolumn{2}{|c|}{$\begin{array}{l}\text { Agua capilar } \\
\text { máxima }\end{array}$} \\
\hline & PAso & Volume & & Péso & Volume & I'êso & Volume & P'ê:so & Volume \\
\hline & $\%$ & $\%$ & & $\%$ & $\%$ & $\%$ & $\%$ & $\%$ & $\%$ \\
\hline $0-40 \mathrm{~cm} \quad-\cdots$ & 8.7 & 4,5 & A. $\mathrm{I}$. & 6,4 & 8,5 & 9,4 & 12,5 & 19.0 & 25,3 \\
\hline $40-80 \mathrm{~cm}$ & 16,9 & 8,4 & B. A. & 7,7 & 10,1 & 11,3 & 14,8 & 21,0 & 27,5 \\
\hline $80-150 \mathrm{~cm} \quad \ldots \ldots$ & 27,2 & 14,1 & B. $\mathbf{L}$. & 9,6 & 13,0 & 14,2 & 19,2 & 23,0 & 31,0 \\
\hline
\end{tabular}

\section{$4-\mathrm{SOIO}$ (BLACIAL}

Área - Fo:am estudados cêrea de 2.000.000 hectares dêsse grande tipo de solo equivalente a $8,1 \%$ da área total do Estado.

Topografia - E suave a topografia dêstes solos, apresentando grandes áreas planas. A altitude varia entre 500 e $750 \mathrm{~m}$ acima do nível do mar.

Geologia - Este grande tipo de solo traz o nome da própria formação geológica a que pertencem as rochas que o originaram. Estas são : varvitos, argilitos, tilitos e arenitos. O estudo mineralógico-petrográfico desta série de rochas mostra variação imensa em sẹtus constituintes minerais. Há casos 

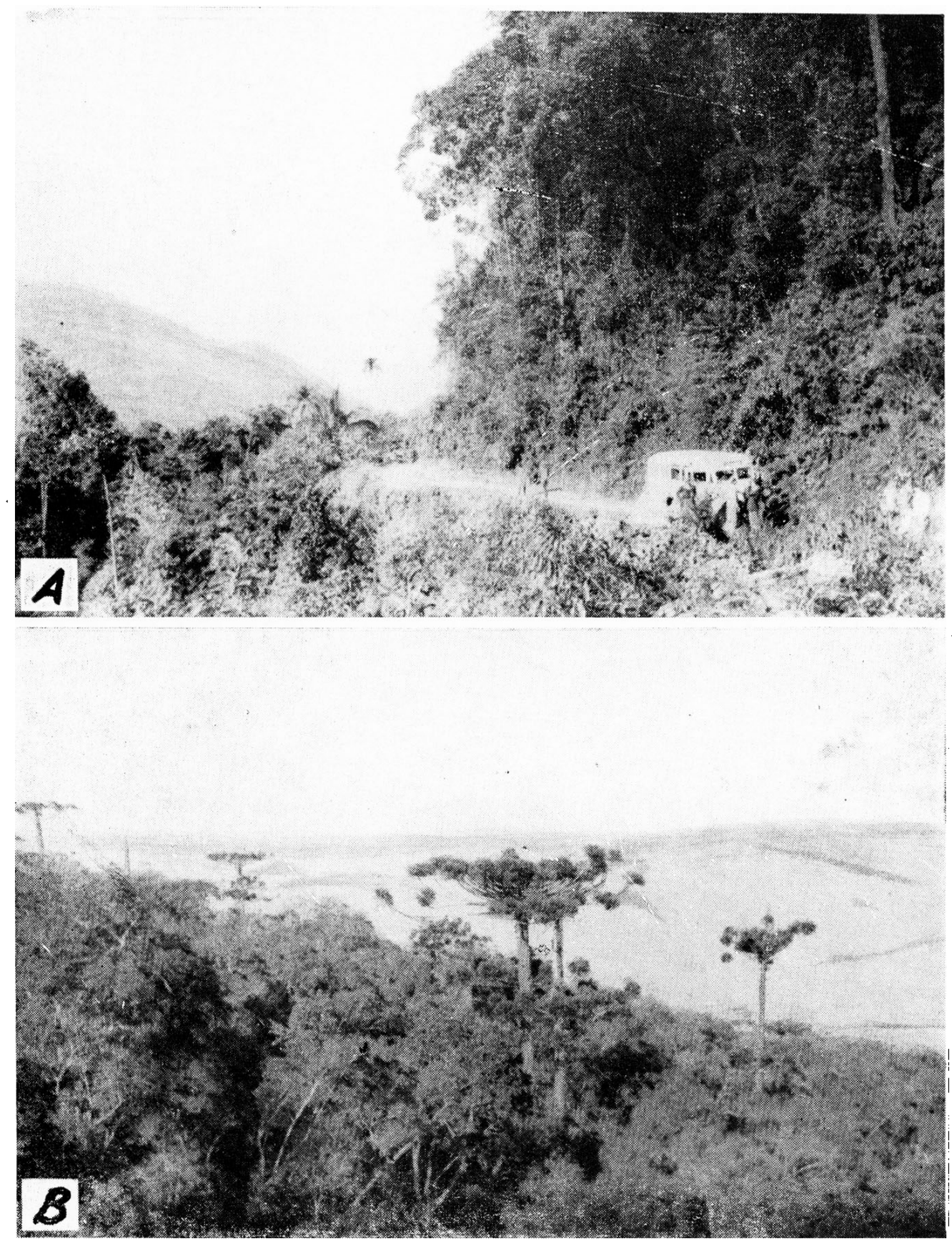

Salmourão-Massapé. Localizaçāo: Descida da Scrra do Mar, em Ubatuba (45̄o10 W. Cr. $23^{\circ} 25 \mathrm{~S}$ ) ; altitude: $1000 \mathrm{~m}$, olservando-se mata pluvial com vegetação primária sôbre rocha-mater de gnaiss e pegmatito; precipitação auual: 2000-3000 mm. B-Devoniano. Localização: SE de Vila Velha, no Paraná (500 W. Gr. 25015' S): altitude: $950 \mathrm{~m}$, vendo-se mata primária típica, sobressaindo al Arancaria angustifolia Rich. 

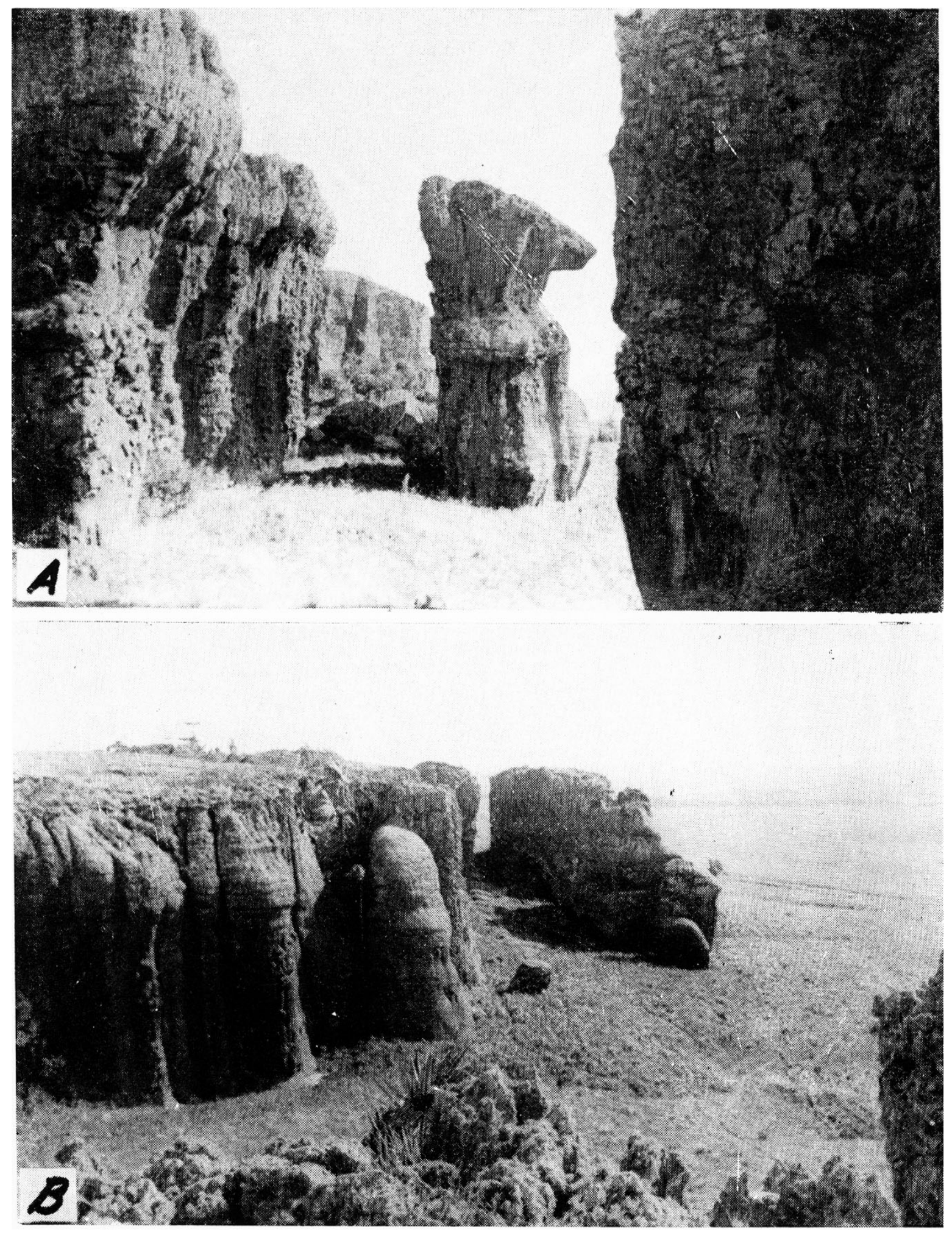

1)evoniano. A e B-Localização: Vila Velha, Paraná (50\%05' W. Gr. 25०15'S) Altitude: $950 \mathrm{~m}$, Observa-se a erosão eólica das escarpas de arenito devoniano. 
de arenitos cuja composição mineralógica é representada, quase que exclu sivamente, por quartzo, existindo também casos de argilitos, varvitos e tilitos, ricos em minerais potássicos, magnesianos e cálcicos. Foram observados, portanto, solos desde argilosos até tìpicamente arenosos nessia formação, e com a mesma denominação genérica. Contudo, boa parte da área em questão, ou seja do grande tipo "solo glacial", é originária dos arenitos pobres, já referidos acima ; portanto, as considerações aqui expostas se referem a êles.

Vegetação natural --- Devemos ressaltar que apenas está sendo considerada a área arenitica ; observam-se, como paisagem florística, campos com barba de bode, indaiá (Altalea indaya Dr.), barbatimão (Stryphnodendron barbatimão Mart.), guabiroba (Abbevilles neriiflora Berg.) e mais uma série bastante grande de subarbustos e arbustos tìpicamente subxerofíticos. Iisa-se mesmo, para êsses tipos de paisagem, a denominação de "campo re pau torto" (Estampa 5-A e $B$ ).

Perfil do solo - São solos em geral claros, acinzentados na stuperfície, e amarelados ou avermelhados na camada mais profunda. Não há horizontes pedológicos bem definidos. Nos primeiros $30 \mathrm{~cm}$ está distribuída grande parte da matéria orgânica em que, aliás, são bastante pobres. São essencialmente arenosos; assemelham-se muito ao grande tipo arenito Botucatu. Possivelmente, para o futuro, será mapeado juntamente com êste último, permanecendo no grande "tipo Glacial" apenas as áreas de solos provenientes de argilitos, varvitos e tilitos, que não estão descritos neste trabalho.

Nos quadros 4 e 5 , pode-se ter melhor idéia da constituição física e química dêste solo $(5,6)$.

Culturas - No geral, pastagens, abacaxi (Ananas sativus (Lindsley) Schultes f.) ; pouco algodão (Gossypium hirsutum L. (Upland)) e série de pequenas culturas.

\section{:) - SOLO (ORUMBATAÍ}

Ârea - E de cêrca de 700.000 hectares, ou sejam, 2,8\% da área total do Estado.

Topografia - $\bar{F}$, no geral, de regular conformação topográfica, apresentando o terreno pequenas ondulações. A altitude varia entre 490 e 740 metros acima do nivel do mar.

Geologia - Este grande tipo de solo se assenta sôbre a formação geológica Corumbataí-Permiano (Série Passa-Dois). As rochas predominantes são : argilitos, folhelhos argilosos com sílex, calcários e arenitos muito finos, quase de textura argilosa, sob ponto de vista granulométrico. A composição petrográfico-mineralógica dessa formação é bastante complexa e variável.

A análise radiográfica da fração argila mostra grande quantidade de quartzo e, às vêzes, apresenta também pequena quantidade de caolinita. Esta fração, que serviu às análises radiográficas, é constitúda por partículas menores do que dois microns (4). 


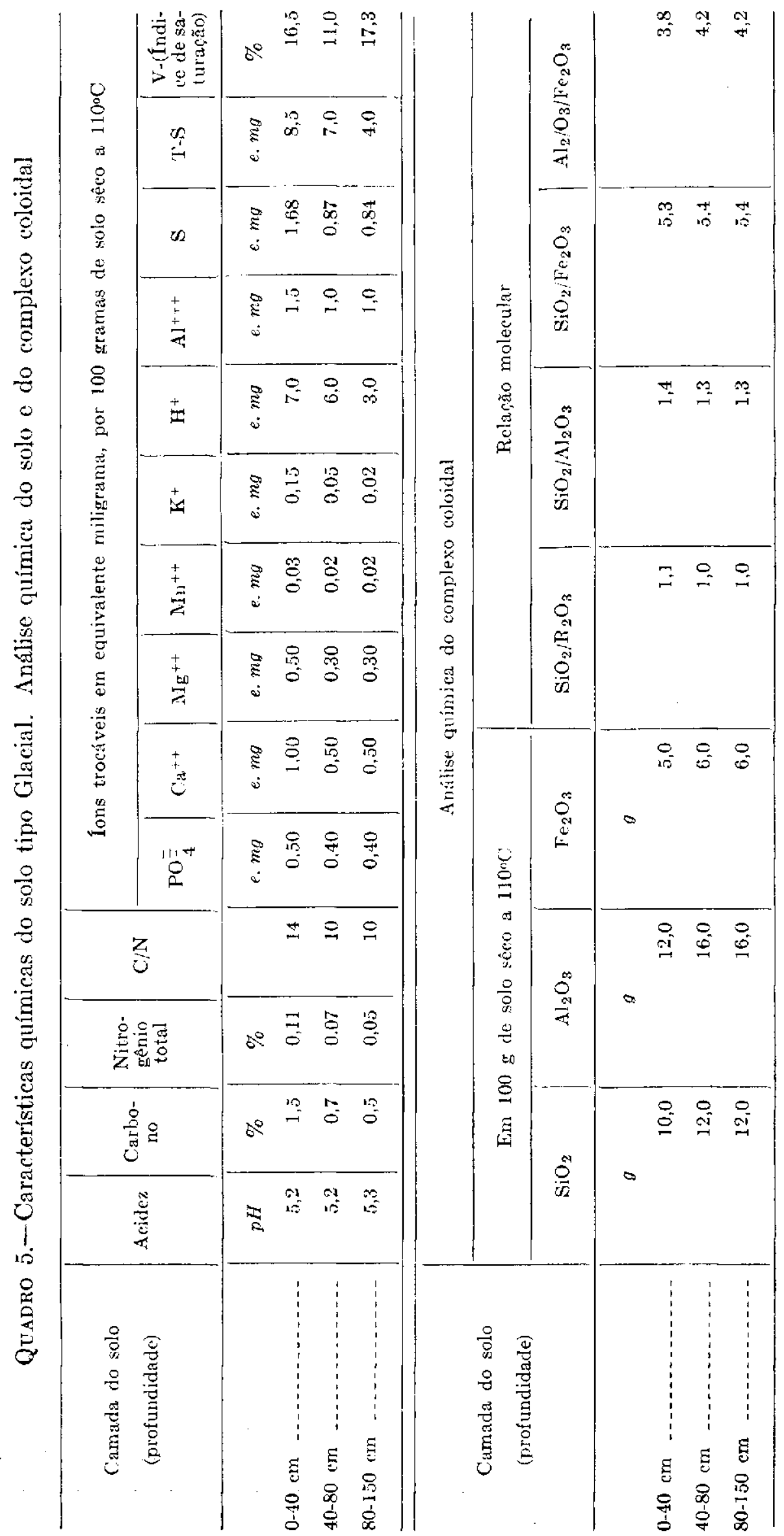


Vegetação natural - A cobertura vegetal natural é comumente regular ; mais ou menos do tipo subhidrofilo; de porte comumente médio.

Perfil do solo - Apresentam, no geral, coloração acinzentada, amarelada e até vermelha. A côr dos primeiros $30 \mathrm{~cm}$ tende geralmente para acinzentado ou pardo marrom, devido ao teor em matéria orgânica; as camadas mais profundas são coradas, como dissemos acima, devido aos óxidos hidratados de ferro.

São solos em geral quìmicamente ricos, tanto em elementos trocáveis, como no estado potencial. Sob o ponto de vista físico, mostram-se rasos, argilosos e pouco permeáveis à água e mesmo às raízes das plantas. O sistema radicular das plantas encontra certa dificuldade em penetrar além de 60-70 $\mathrm{cm}$ de profundidade. $\mathrm{O}$ quadro 6 , com dados químicos, completa esta rápida descrição (5).

\section{6-SOLO ARENITO BOTUCATU}

Área-Cêrca de 7.200.000 hectares dêsse grande tipo de solo estão sendo estudados, já há 15 anos. Essa área equivale a cêrca de $29,1 \%$ do total do Estado de São Paulo.

Topografia - Em quase sua totalidade, completamente plano; é especial para o emprêgo, em larga escala, de maquinaria agrícola. As altitudes oscilam entre 450 e $900 \mathrm{~m}$ acima do nível do mar.

Geologia - As formações geológicas, que deram origem a êsses solos, são as mesozóicas, (') constituídas por rochas areníticas de formação eólica, o que se observa claramente ao estudar as superfícies dos grãos de quartzo que os constituem. A formação pode ser observada em série de planaltos originados por falhas geológicas.

A constituição petrográfico-mineralógica dêsses arenitos é bastante pobre, pois se constitui quase que exclusivamente de quartzo cimentado por géis de sílica, óxidos de ferro e alumínio mais ou menos hidratados, e, possivelmente, argila. A coloração em geral é rósea ou avermelhada ; encontra-se também a côr creme e branca, conquanto em menor percentagem. Este arenito se destaca fàcilmente em lages, isto é, possui planos de clivagem geralmente distanciados uns dos outros cêrca de 6 a $8 \mathrm{~cm}$ (Estampa 6 A e B). Algumas vêzes, apresentam-se bem friáveis, outras vêzes fortemente cimentados, podendo ser considerados como arenito-quartzítico. Nas zonas de contacto com as eruptivas básicas, apresentam-se fortemente cozidos.

Vegetação natural - Neste grande tipo de solo encontram-se grandes áreas em forma de campo de barba de bode e indaiá (estampa 6-B e 7-A), guabiroba, barbatimão, cambará do campo (Lantana camara L.), bromeliáceas, etc. mostrando paisagem tìpicamente subxerófita. Encontra-se esta paisagem sobretudo na área leste da formação. Já na zona oéste, encontramos vegetação arbórea natural, considerada como "boa mata" primária, onde se encontra grande quantidade de peroba (Aspidosperma olivaceum M. Arg.), ipê, (Tecoma : spp.) etc., dando já idéia de paisagem sub-

(1) Conforme mostra a figura 3, sob a denominaşāo de arenito Botucata, foram reunidos os solos procedentes das formaçóes Botucatá e Caiú, que estão mapeadas separadamente na Carta Geológica do Fetado de Săo Paulo. 


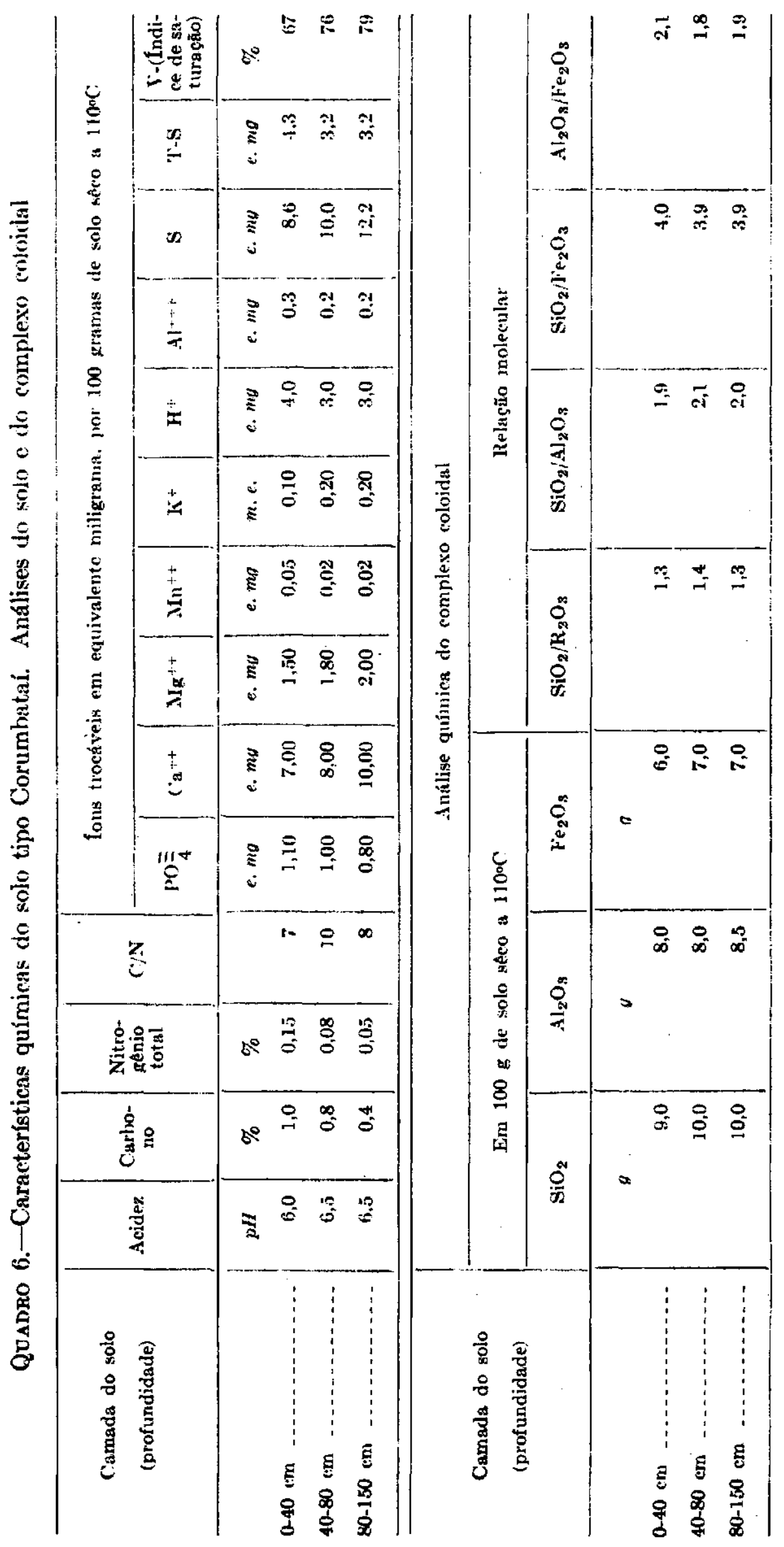



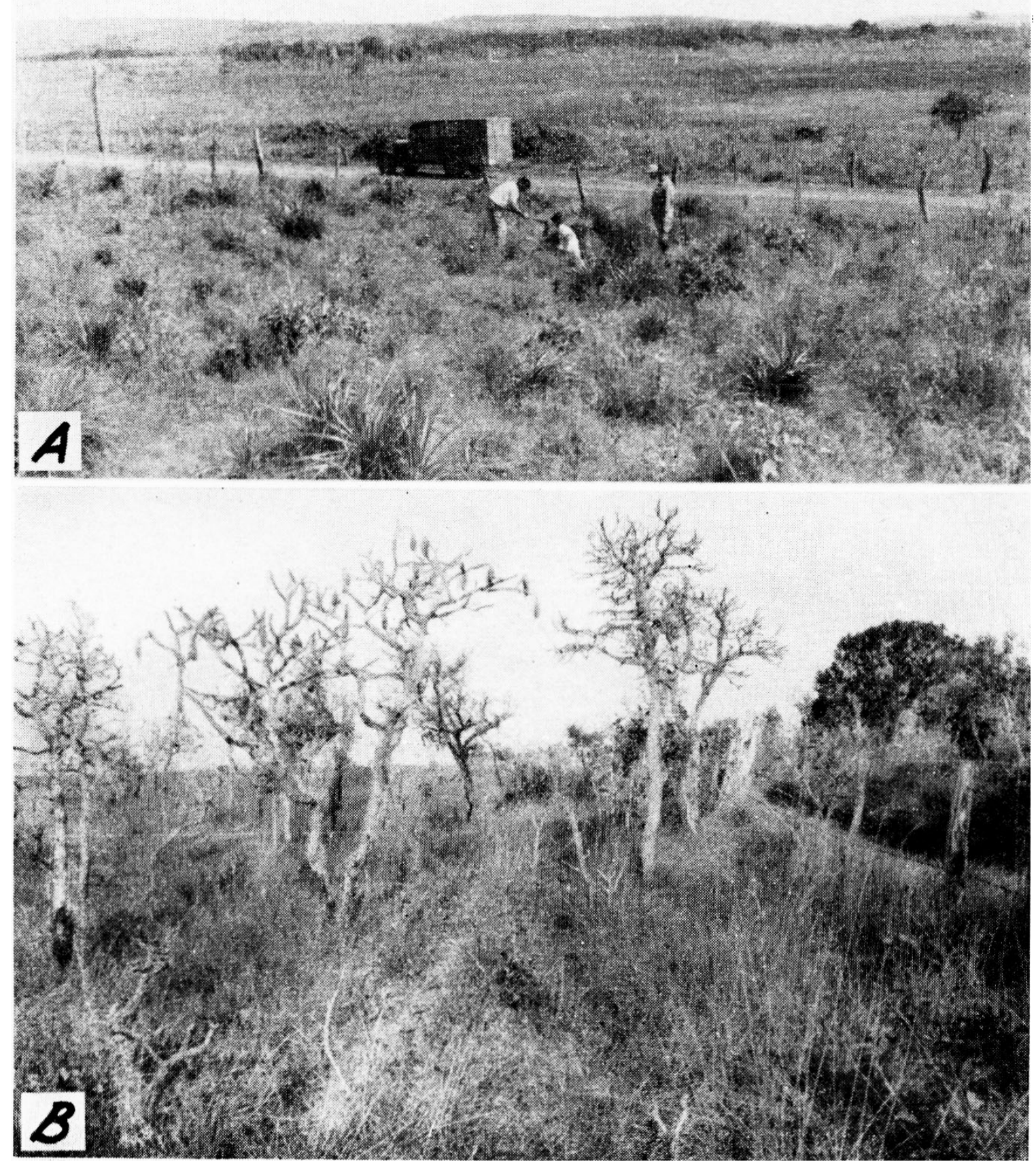

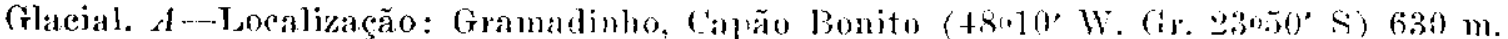
Vegetação e topografia típica. Fim primetro plano vê-se Bromelia fastuosa

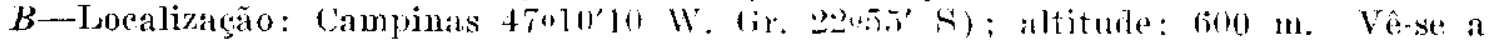
vegetação subxerófita dêstes solos. 

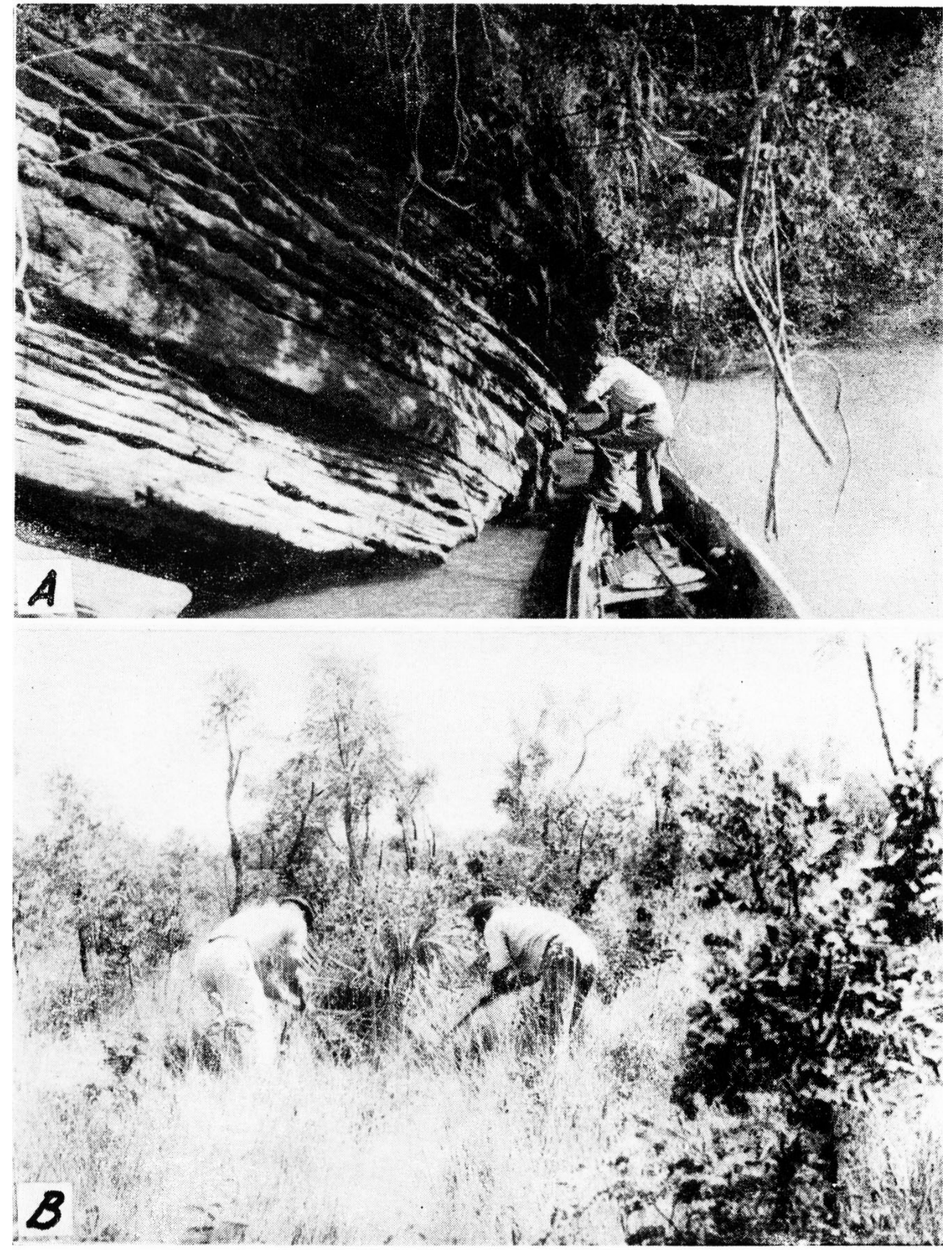

Arenito Botucatu. A-Localizaçăa: Margen: do Ric Panáa (53005' W Gr. geos5' S); altitude: $200 \mathrm{~m}$. Catmadas de arenito resado de granulaşāo uniforme, resistente. $B$-Localização: Analândia, em șāo (artos (47050' W. Gr. 20005' s) ; altitude: $800 \mathrm{~m}$. Típica regetação xerófita. Observa-se a retirada de uma Attulea Indaya Drudo. 
hidrófila ou, pelo menos não subxerofítica. A razão provável dêste fenômeno está na existência de grandes rios, tais como: o do Peixe, Aguapé, Tietê, etc., que irrigam melhor essias zonas areníticas. Entretanto, depois das derrubadas, e após exploração agrícola dêstes solos, não mais tem voltado a vegetação natural, a não ser do tipo subxerofítico.

Perfil do solo - Estes solos, em geral, se mostram de côr clara, cinzenta, amarelada e mesmo avermelhada. São tìpicamente arenosos e pobres em matéria orgânica. Nos primeiros $30 \mathrm{~cm}$ de solo está em geral distribuifa grande parte da matéria orgânica ; por êste motivo essa camada é, em geral, acinzentada e mesmo marrom. Abaixo dos $30 \mathrm{~cm}$ já se torna amarelada ou avermelhada ; deve-se esta coloração a compostos oxigenados: mais ou menos hidratados de ferro. Pràticamente, não há diferenciação pedológica de horizontes no perfil dêste solo. São originàriamente pobres em elementos químicos importantes ao desenvolvimento das plantas. Segundo a análise química, o arenito eólico (rocha-mater dêste tipo de solo) é paupérrimo em potássio, cálcio, magnésio e fósforo.

São solos bastante profundos, muito permeáveis à água. Por êste motivo, o lençol dágua, no geral, está a grande profundidade, permitindo a êsses solos manter apenas vegetação subxerofítica. São também solos quìmicamente pobres em elementos trocáveis e em elementos no estado potencial. Não se notam, na análise mineralógica das frações areia grossa e areia fina + limo, minerais que possam fornecer às plantas : potássio, cálcio, fósforo, magnésio, etc. No quadro 7 , são dados os resultados de uma análise cuímica média do perfil de solo em questão (5).

A fração argila dêsses solos é constituída essencialmente por cuolinita, hidrargilita e quartzo. Em $100 \mathrm{~g}$ da fração argila, são encontrados cêrra de $50 \%$ de caolinita, sendo o restante constituído pelos outros dois componentes. Estas determinações qualitativas foram executadas por meio de radiografia (método de Debeye-Scherrer) (4). Como se vê pela análise mecânica (quadro 8) e pelas demais determinações físicas, êste solo é tipicamente arenoso (6). As estampas 6-A e $B$ e $7-A$ mostram vistas típicas dêsses solos. Além de excessivamente arenosos, as partículas de quartzo são bastante arredondadas pelo trabalho eólico, o que muito facilita 0 fenômeno da crosão. São solos bastante indicados para receber o reflorestamento com eucalíptos.

Culturas principais - Algodão e milho (Zea mays I..).

\section{7 - TERRA ROXA LWGÍTIMA}

Área - Foram estudados cêrca de 1.700 .000 hectares de terra roxa legítima, ou sejam, cêrca de $7,3 \%$ da área total do Estado de São Paulo.

Topografia - Esse grande tipo de solo possui topografia, em geral, amena; entretanto, em alguns pontos do Estado, encontramos encostas mais ou menos acidentadas. A altitude varia entre 480 e $900 \mathrm{~m}$ acima do nível do mar, grande parte, porém, está situada entre 500 e $700 \mathrm{~m}$. 


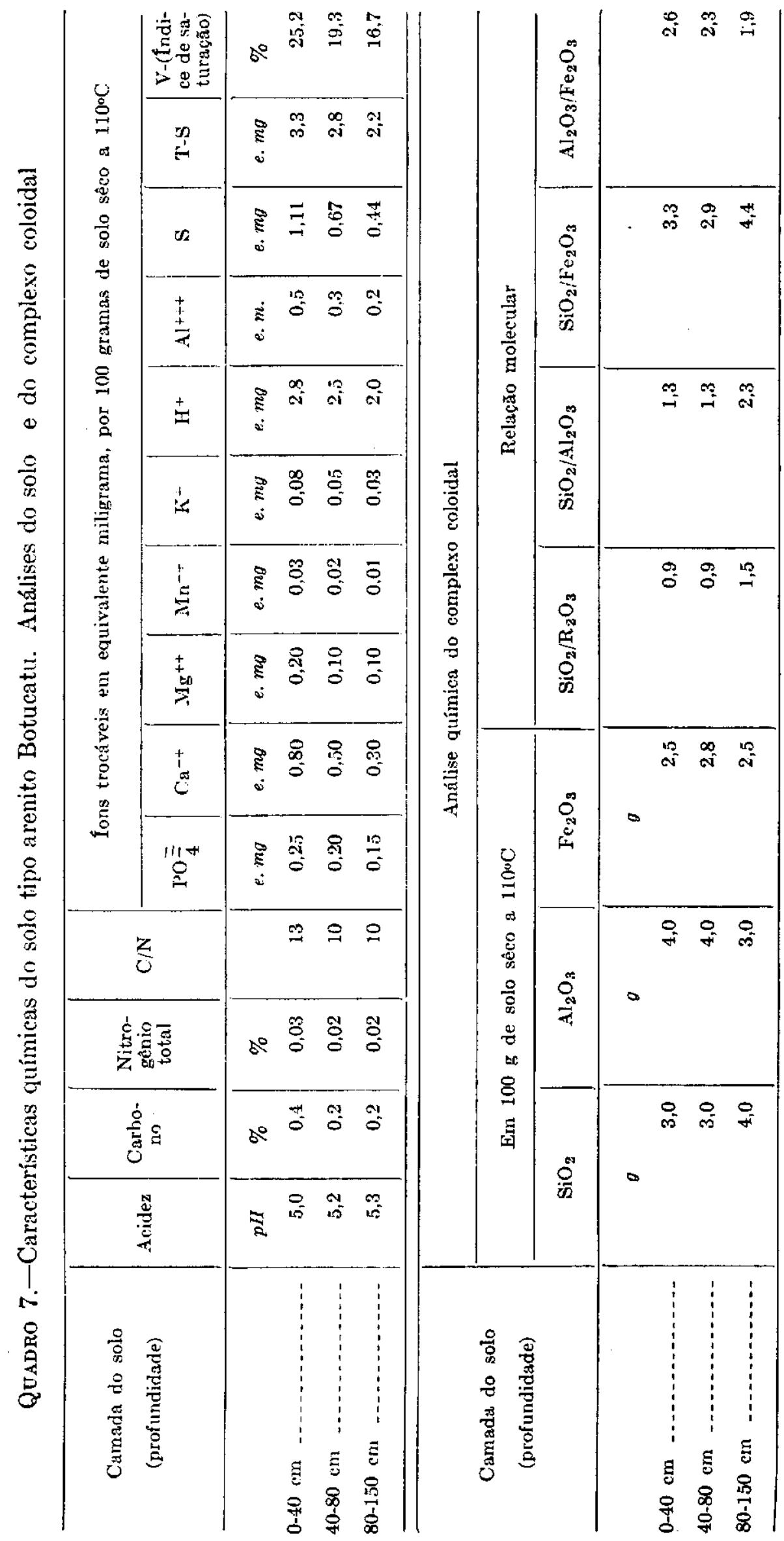



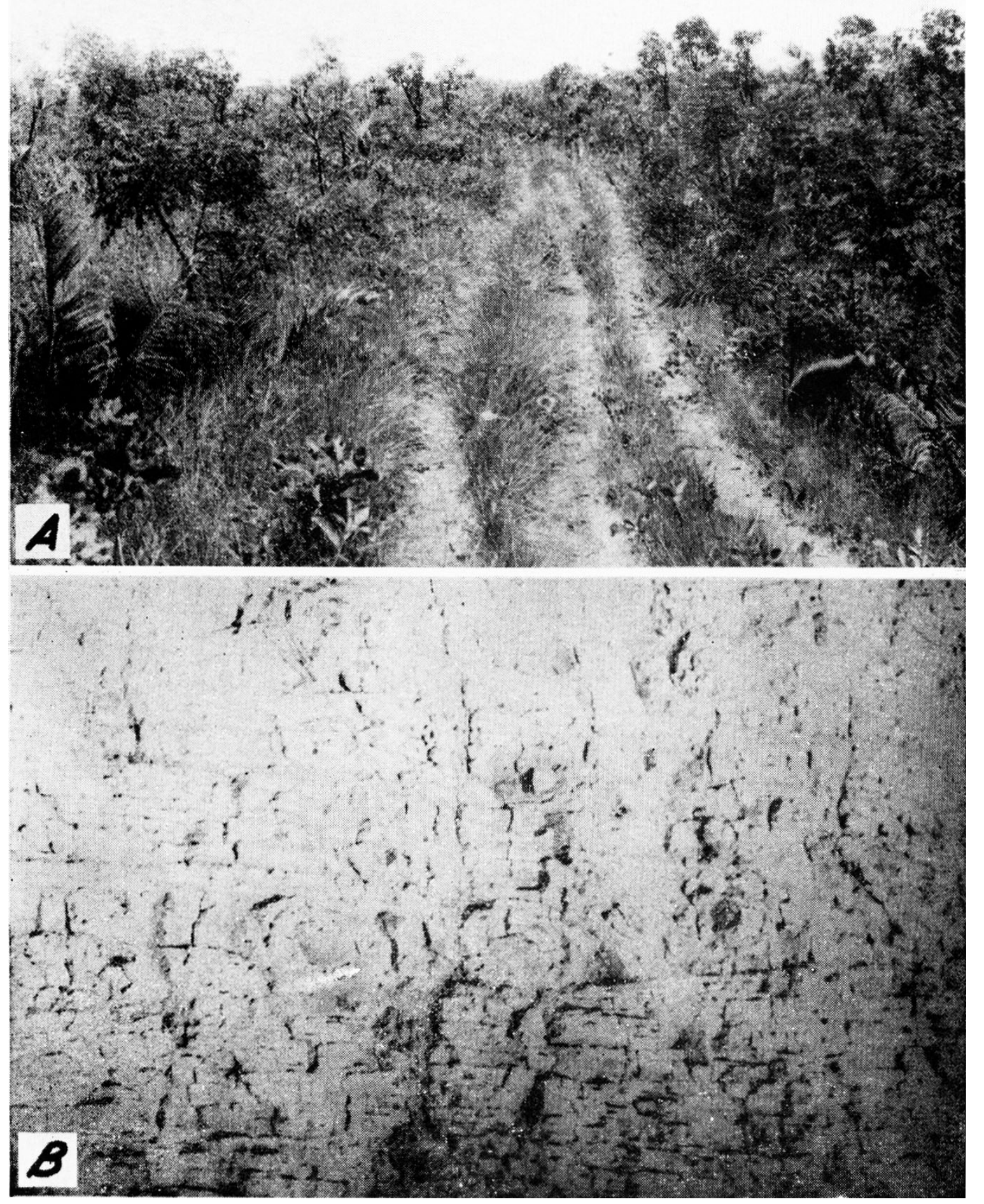

A-Arenito Botucatu. Localização: Analândia, em São Carlos 47050' W. Gr. 20005' S) ; altitude: $800 \mathrm{~m}$. Vegetaçăo subxirófita típica. $B$-Terra roxı legítima. Iocalização: Botucatu (48025' W. Gr. 22,55' S) ; altitude: $530 \mathrm{~m}$. Corte em diabásio decomposto, provàvelmente por fenômenos anteriores à época gcológica atual. 

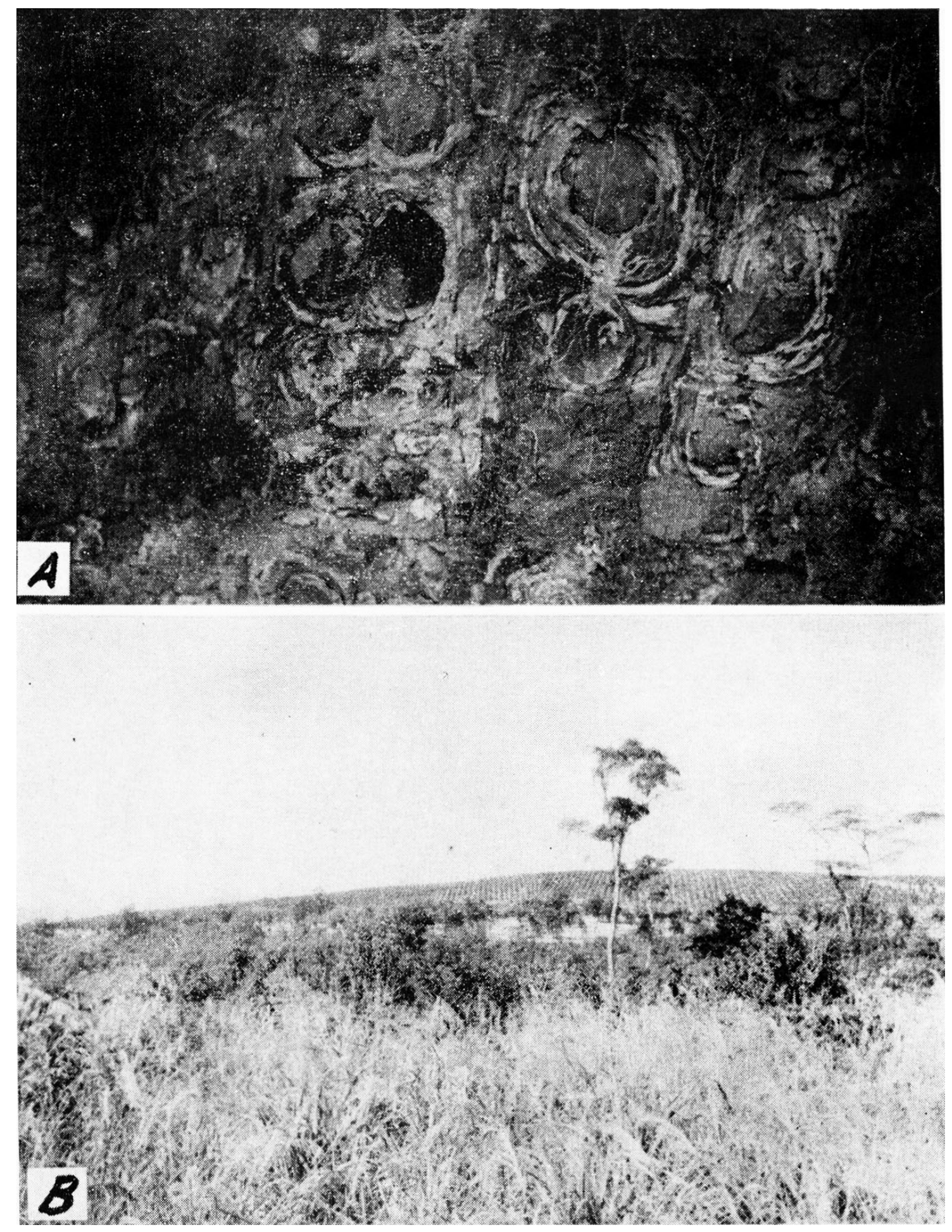

1-Tcrua roxa legítima. Tocalizaçăo: Aunlândia 47040' W. Gr. 22005' S.) ; altitude: 690 u. Decomposiçāo colicêntriç do dia búsio devido, provàvelmente, a fenômenos de intemperismo atual. $B$-Arenito Buuru. Localização: Marília, Rio do Peixe $\left(49055^{\prime}\right.$ W. Gr. $\left.22015^{\prime} S\right)$; altitude: $625 \mathrm{~m}$. Olsserva-se a topografia, típica dêste tijo de solo, tendo no fundo uma cultura de café. 
Geologia - A idade geológica é a triásica-jurássica. O magma diabásico, ou sejam as eruptivas básicas, são as rochas responsáveis pela origem dêsse grande tipo de solo e a sua composição mineralógica é variável (3).

A terra-roxa-legítima provém de rochas diabásicas. Contudo, pelos estudos sôbre a gênese dêsse solo, ainda em andamento, podemos subdividi-lo nos dois subtipos :

a) Solos de terra roxa legítima proveniente de produtos de decomposição antiga do magma diabásico, isto é, de fenômenos geológicos, cuja idade é a mesma das erupções básicas.

b) Solos de terra roxa legítima proveniente de produtos de decomposição procedente do intemperismo da época atual.

No primeiro caso, as capas de decomposição mostram, em geral, fenômeno intenso de caolinização, ac passo que no segundo, pràticamente, a totalidade do $\mathrm{Al}_{2} \mathrm{O}_{3}$ está livre e solúvel no $\mathrm{HCl}$ concentrado e a quente, e o $\mathrm{SiO}_{2}$ na forma coloidal. No primeiro, a intensidade da lixiviação tanto das bases como do $\mathrm{SiO}_{2}$, foi menor do que no segundo caso.

Para encontrarmos os dois extremos, isto e, a elevada riqueza de bases na rocha viva, e o baixo teor em bases da capa decomposta, como ficou dito acima, bastam apenas cêrca de $2 \mathrm{~cm}$ de espessura. A análise química dos trocáveis, no material da capa de decomposição, é pràticamente idêntica à encontrada em camadas de solo à profundidade de cêrca de $2 \mathrm{~m}$ para baixo.

Vegetação arbórea natural - Jequitibá (Cariniana sp.), Peroba (Aspidosperma olivaceum M. Arg.), Jangada-branca (Heliocarpus americanus L.), Pau d'alho (Gallesia gorazema Moq.), Ceboleiro (Phytolacea dioica L.), Araruta (Centrolobium tomentosum Benth.), etc. Matas, geralmente consideradas boas e do tipo subhidrófilo.

Perfil do solo - Constitui um perfil autóctone de terra roxa legítima "sui generis", principalmente dada sua grande porosidade que é da ordem de 65 a $70 \%$, embora de composição mecânica quase a ser considerada argilosa.

Sua coloração é bem típica e muito difícil de ser traduzida para outro idioma, a não ser por meio de anotações das tabelas de côres, tais como "Tabela Internacional de côres de Ostwald" ("Uebersichtsplan Farbnormenatlas von Wilhelm Ostwald. Verlag Unesma G.m.b.H. GrossbothenLeipzig"), empregada em nossos trabalhos.

A tradução ao pé da letra da palavra "roxo" para a língua inglêsa seria "violet", o que, sem dúvida, não corresponde bem, ou pelo menos não corresponde ao que um desconhecedor poderia esperar de tal tipo de solo, quando o visse pela primeira vez. Na tabela de côres citada, essa côr "roxa" está compreendida entre ng5 para o solo sêco e pi6 para o solo úmido, o que talvez corresponda melhor à tradução de marrom-avermelhado. Pràticamente, não há variação de côres nas diversas profundidades do perfil. As estampas 7- $B$ e 8- $A$ mostram diabases em decomposição, que dão origem a terra roxa legítima.

São solos em geral muito profundos, podendo-se chegar a $20 \mathrm{~m}$ sem encontrar rocha, mesmo semidecomposta. 
Quanно 8.-Características físicas do solo tipo arcuito Botucatu. Dados gerais, análise mecânica total e fase líquidn

\begin{tabular}{|c|c|c|c|c|c|c|c|c|c|}
\hline \multirow{2}{*}{$\begin{array}{c}\text { ('anada do solo } \\
\text { (yrofundidade) }\end{array}$} & \multicolumn{2}{|c|}{ Massa especifica } & \multirow{2}{*}{$\begin{array}{c}\text { P'orosi- } \\
\text { dade } \\
\text { natural }\end{array}$} & \multicolumn{2}{|c|}{$\begin{array}{l}\text { ('ór do solo } \\
\text { (Ostwald) }\end{array}$} & \multicolumn{2}{|c|}{$\begin{array}{l}\text { Areia grossaz } \\
(2 \text { a } 0,2 \text { mn! })\end{array}$} & \multicolumn{2}{|c|}{$(0,2$ a $0,002 \mathrm{~mm})$} \\
\hline & Rea! & Aparente & & Ímirdo & seco & l'ento & Volume & P'ÉO & Volume \\
\hline \multirow{3}{*}{$\begin{array}{l}0 . \\
0-10 \mathrm{rni} \\
40-80 \mathrm{~cm}\end{array}$} & & & $\%$ & & & $\%$ & $\%$ & $\%$ & $\%$ \\
\hline & 2,60 & 1,29 & 5), 4 & ig 3 & jo 3 & 74,3 & 37,7 & 17.9 & 8,8 \\
\hline & 2,60 & 1,29 & $51, \pi$ & is .7 & ie +4 & 70,2 & 34,8 & 18,8 & 4,0 \\
\hline $80-1 ; 0)(m, \quad \ldots$ & 2,68 & 1,40 & 47,8 & ie $j$ & in 4 & 61,7 & 32,2 & 24,3 & 12.7 \\
\hline \multirow{2}{*}{$\begin{array}{c}\text { (anatda so solo } \\
\text { (profundictade) }\end{array}$} & \multicolumn{2}{|c|}{$(<\underset{0,002}{\text { Argilis }}$} & \multirow{2}{*}{$\begin{array}{l}\text { Indire } \\
\text { intern. } \\
\text { (Buitei- } \\
\text { zorg) }\end{array}$} & \multicolumn{2}{|c|}{$\begin{array}{l}\text { Umidade de } \\
\text { nuturchanento }\end{array}$} & \multicolumn{2}{|c|}{$\begin{array}{l}\text { Umidade equi- } \\
\text { valente }\end{array}$} & \multicolumn{2}{|c|}{$\begin{array}{l}\text { Agua rarilar } \\
\text { mixima }\end{array}$} \\
\hline & Pêso & Volume & & l'êso & Volume & Pêso & Volume & Pêto & Volume \\
\hline & $\%$ & $\%$ & & $\%$ & $\%$ & $\%$ & $\%$ & $\%$ & $\%$ \\
\hline 0-40 & 7,8 & 3,8 & A. & $\overline{5}, 0$ & 6,4 & 7,3 & 9,4 & 10,1 & 13,0 \\
\hline $40-80 \mathrm{~cm}$ & 11,0 & 5,2 & A. $B$. & $\overline{5}, 6$ & 7,2 & 8,2 & 10,6 & 10,7 & 13,8 \\
\hline $80-150 \mathrm{~cm} \quad \ldots .$. & 14,0 & 7,3 & A. 13. & 6,8 & 4,5 & 10,0 & 14,0 & 11,2 & 15,7 \\
\hline
\end{tabular}

Quando ainda de posse de sua textura natural, são permeáveis. Entretanto, depois de 20 a 30 anos de cultura, em geral, se forma um horizonte iluvial impermeável, entre 30 e $60 \mathrm{~cm}$ de profundidade. Este horizonte não só impede a penetração da água, como também dificulta a penetração das raízes das plantas. A matéria orgâniea está $\mathrm{em}$ seus $80 \%$ distribuída nos primejros $40 \mathrm{~cm}$ de solo; o mesmo acontecendo com as bases trocáveis. Estas vão diminuindo até atingir um teor mais ou menos constante para profundidades maiores do que $2 \mathrm{~m}$ e que é da ordom de 1 a $1,5 \mathrm{e} . \mathrm{mg}$ por $100 \mathrm{ml}$ de solo natural.

A análise mineralógica revela que, pràticamente, não existem mais minerais primários da "rocha mater", a não ser : quartzo em pequena percentagem, isto é, da ordem de 1 a $6 \%$; ilmenita c magnetita. Fm parte, talvez, êstes minerais sejam de formação secundária. A quase totalidade do material é constituída por cêrca de $15 \%$ de caolinita; $\mathrm{Al}_{2} \mathrm{O}_{3} \mathrm{nH}_{2} \mathrm{O} ; \mathrm{Fe}_{2} \mathrm{O}_{3} \mathrm{nH}_{2} \mathrm{O}$ ) $\mathrm{SiO}_{2} \mathrm{nH}_{2}$ (). O magnésio e o potássio, além de se encontrarem na forma tìpicàmente trocável, provàvelmente, ainda se apresentam na parte interna dos géis de sílica ou ślica e alumínio, com estrutura talvez já criptocristalina e que fàcilmente se decompõe por $\mathrm{HCl}$ diluído $( \pm 5 \mathrm{~N})$ e a quente $(1)$. O teor cm magnésio e potássio neste estado pode atingir até $11 / 2$ vêzes o teor trocável do elemento respectivo. Pela fluorização, ou seja, pelo ataque total da terra fina, foram obtidos teores em potássio e magnésio representando o dôbro do teor trocável (1). 


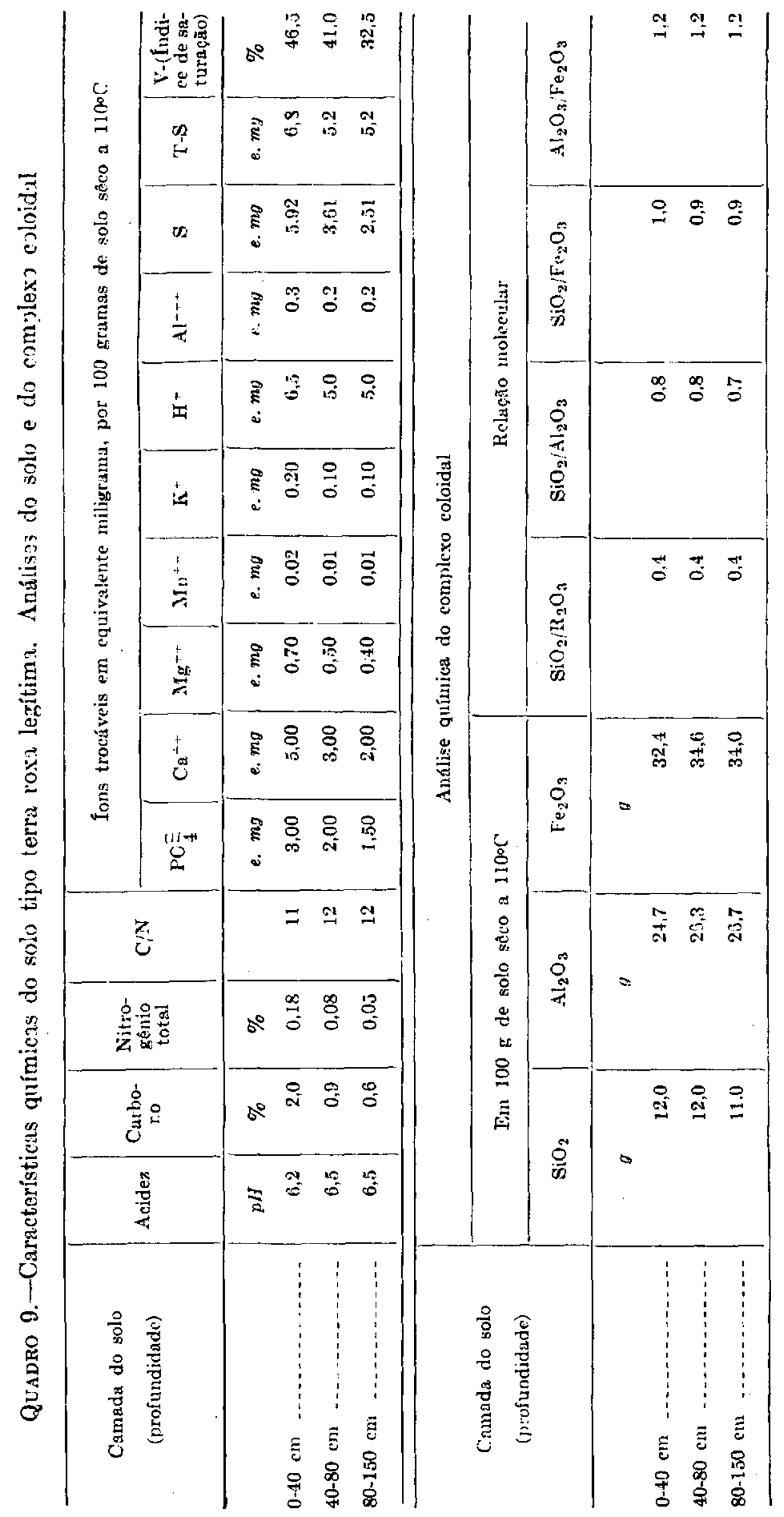


Dados químicos - Quando novos, êstes solos são de grande fertilidade e considerados ricos em elementos químicos minerais. O poder sortivo, relativo às bases, provém "in totum" da matéria orgânica. Em solos novos, ou melhor, de recente derrubada, a parte acidóide orgânica está quase totalmente saturada pelas bases ; neste caso, o indice $\mathrm{pH}$ é da ordem de 7 . $O$ fósforo não orgânico está em grande parte ligado aos hidróxidos mais ou menos hidratados de ferro e alumínio. Baseado em trabalhos já executados e nos ainda em andamento, pode-se admitir que os tipos de ligação entre o $\mathrm{PO})_{4}^{-}$ e os sesquióxidos são os mais diversos possíveis, isto é, desde quantidades infinitesimais solúveis em água até, provàvelmente, aos fosfatos de ferro e alumínio, já em estado pelo menos criptocristalino.

Esta situação faz com que o $\mathrm{PO}_{4}^{\cdots-}$ se encontre en todos os gradientes de extração possível, dificultando, assim, a fixação de um método de extração que nos forneça o fósforo mais ou menos assimilável pelas plantas. Análises químicas médias dêste solo podem ser vistas no quadro 9.

Dados físicos - Segundo análise mecânica, êstes solos são classificados como BA, isto é, "barro argiloso", no quadro internacional de classificação de análise mecânica de Buitenzorg. A textura intima dos grânulos é tìpicamente argilosa, entretanto, no geral, fortemente cimentada, de forma a exigir uma peptização mecânica enérgica. A composição química da fração fina dêstes solos, como dissemos, é essencialmente constituída por óxidos mais ou menos hidratados de ferro e alumínio e sílica coloidal. Trata-se, portanto, de material que, por simples envelhecimento coloidal, possui grande tendência a forte cimentação. Este estado de cousas dificulta em muito, o estabelecimento de técnica razoável e execução de análise mecânica. E esta dificuldade ainda agravada pela grande instabilidade da suspensão, pois a facilidade em flocular é imensa. Esste problema tem sido em parte resolvido usando-se como peptizantes: carbonato de amônio (7), silicato de sódio e mesmo eletrólitos coloidais orgânicos. A peptização é, no geral, facilitada usando um pistilo de borracha, para desfazer os grânulos secundários. No quadro 10, que reproduz alguns dados físicos, podemos observar quão interessante é a massa específica real e aparente dêsse grande tipo de solo. Não há outro no Estado que apresente porosidade tão grande como êste ; observam-se em perfis autóctones, comumente, $70 \%$ de poros, ou sejam $30 \%$ sòmente de "fase sólida". Isso faz necessário o estabelecimento de métodos especiais para os testes físicos. Tanto é assim que, no geral, não podem ser aplicadas a êsses solos as teorias encontradas sobretudo na literatura européia e americana. Isto, máxime nos problemas de água no solo (6).

Culturas importantes -- Café (Coffea arabica L), cana (Saccharum sp.), milho, algodão, amendoim (Arachis hypcgæa $\mathrm{I}_{\text {. }}$ )

\section{8 - SOLO ARENITO DE BAURU}

Área - A área dêsse grande tipo de solo no Estado compreende 6.200.000 hectares, perfazendo cêrca de $25,1 \%$ da área total. 


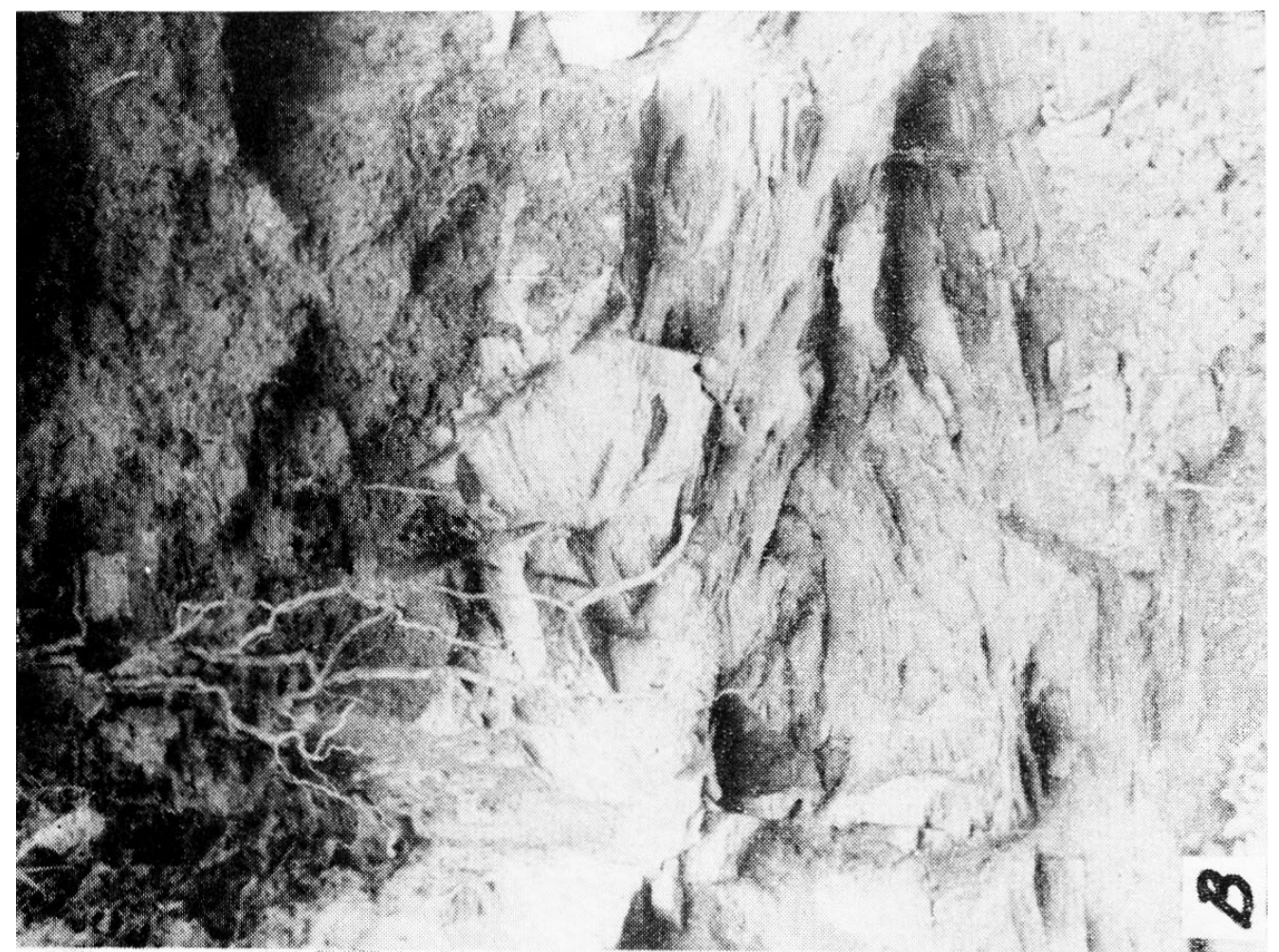

$\stackrel{\circ}{\stackrel{0}{0}}$

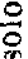

岁
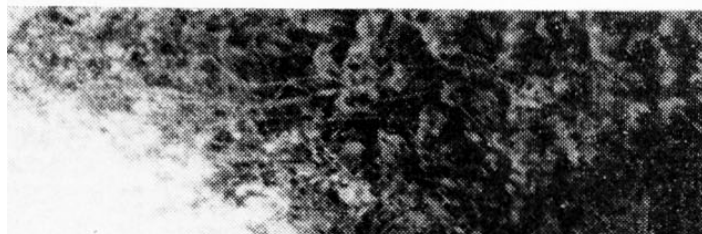

a. 8
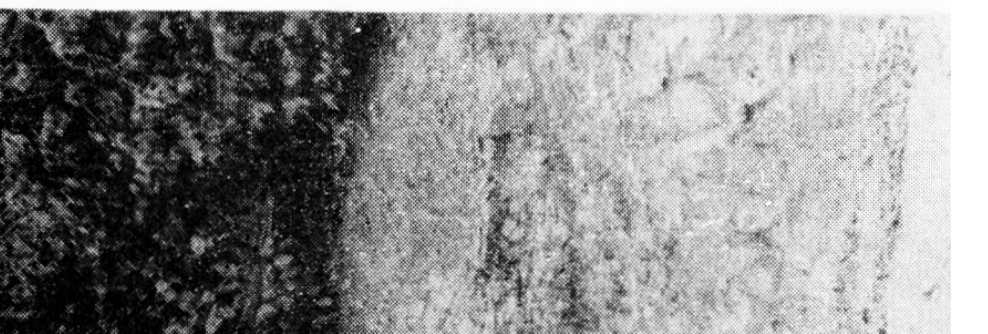

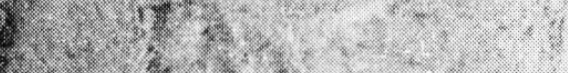
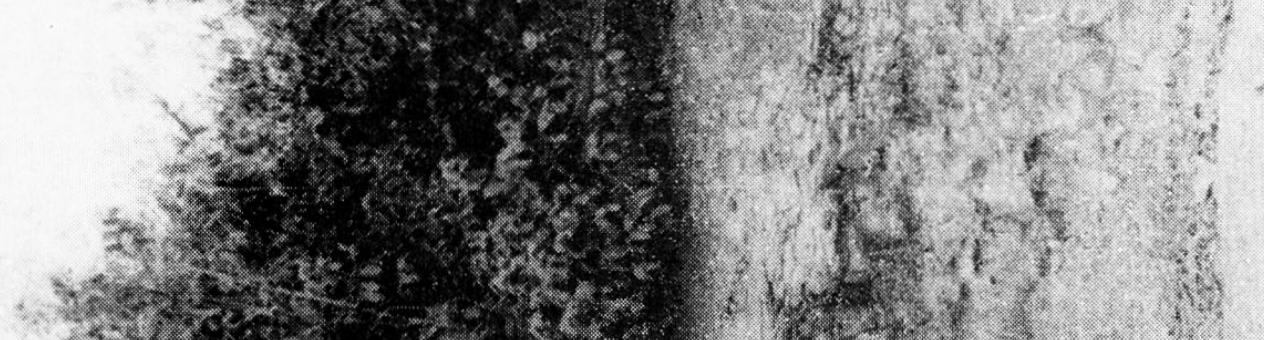

y $x^{2}-t^{2}+t^{2}$

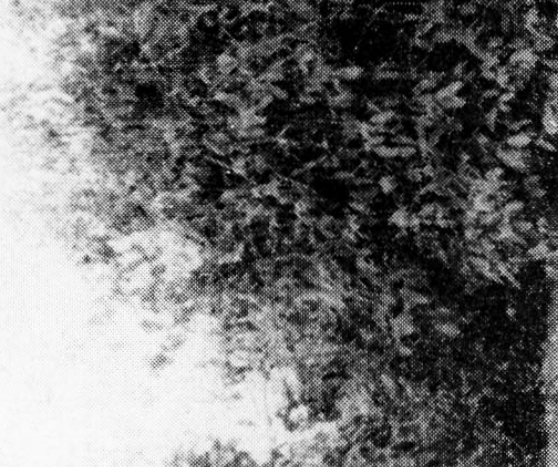
…
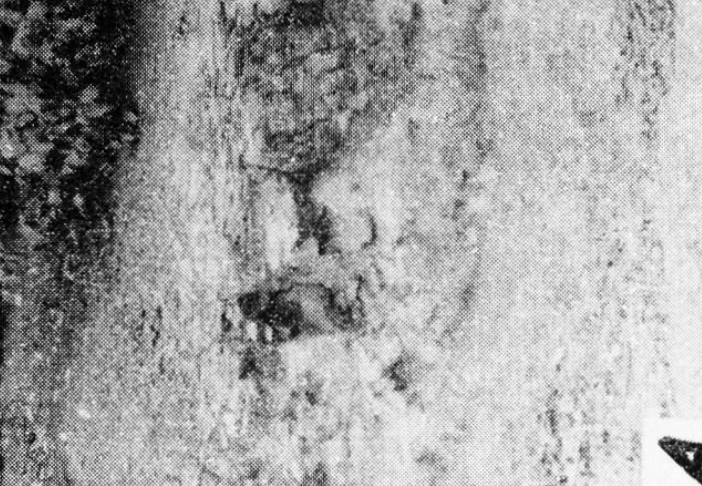

beris

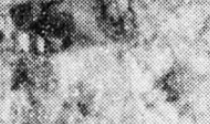

3

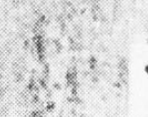

$3: 3$

+its

$\because 1$

$\dot{\vec{E}}$

$=$

is 2

离苞

.

刍

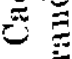

菜

5

芯芯

$\ddot{0} \stackrel{2}{=}$

:

突品

풍

今

$\checkmark \frac{0}{0}$

串 

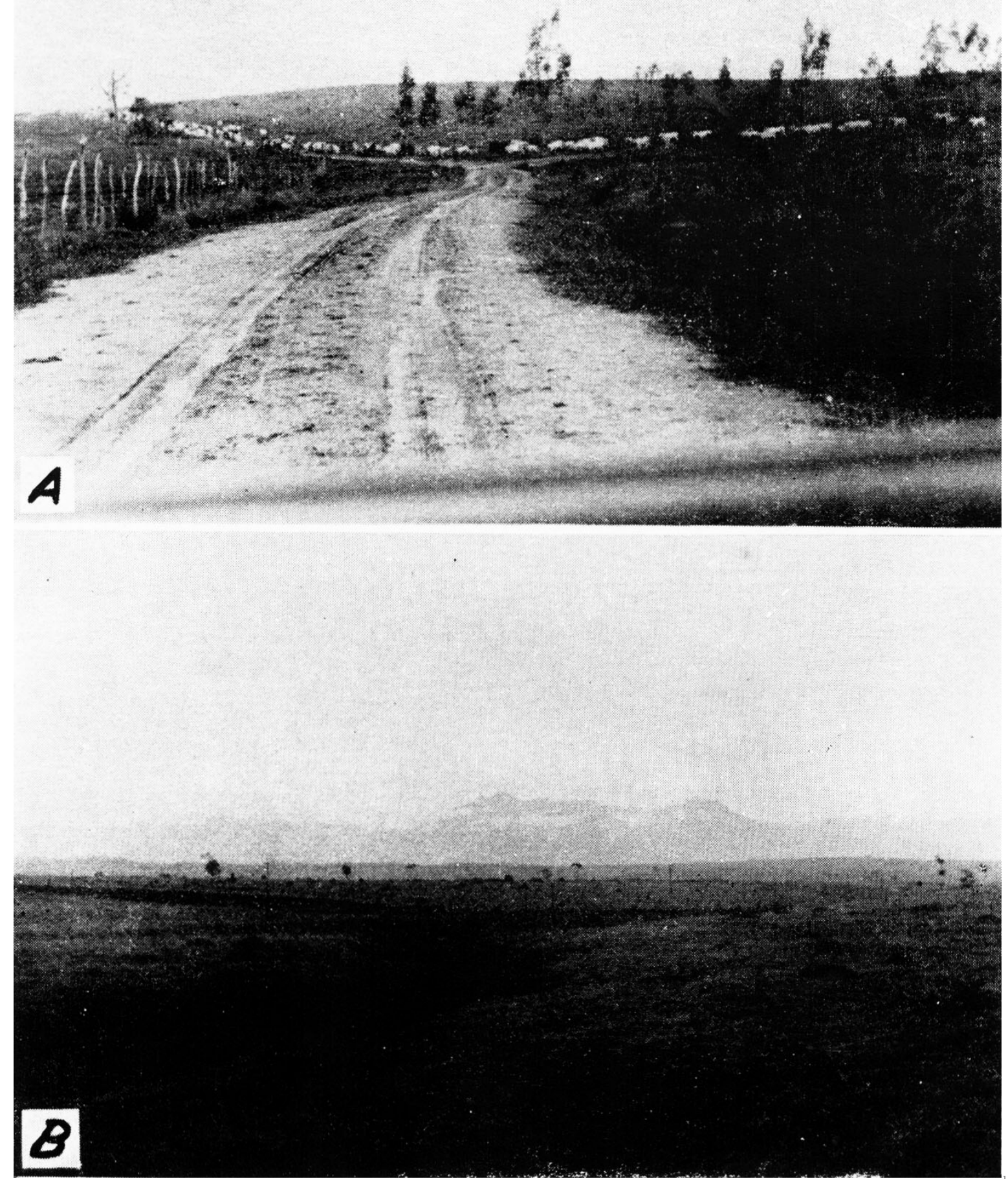

Tereiário. A-Localizaçũo: Pindamonhangaha (45u25' W. Gr. 22045' S); altitude: $560 \mathrm{~m}$. Antigo cafèzal, atualmente pastagem. B-Loralização: Lorena, Cachocira Paulista (45005' W. Gr. 22040' S) ; altitude: 530 m. Fastagem eom capim gordurn, exploração tíliea da regiăo. Ao fundo, a Serra da Malutiqueira. 
QUadRo 10.-Características físicas do solo tipo terra roxa legítima. Dados, análise mecânica total e fase líquida

\begin{tabular}{|c|c|c|c|c|c|c|c|c|c|}
\hline \multirow{2}{*}{$\begin{array}{l}\text { Camada do solo } \\
\text { (profundidade) }\end{array}$} & \multicolumn{2}{|c|}{ Massa especifica } & \multirow{2}{*}{$\begin{array}{c}\text { Porosi- } \\
\text { dade } \\
\text { natural }\end{array}$} & \multicolumn{2}{|c|}{$\begin{array}{l}\text { Côr do solo } \\
\text { (Ostwald) }\end{array}$} & \multicolumn{2}{|c|}{$\begin{array}{c}\text { Areia grossa } \\
(2 \text { a } 0,2 \mathrm{~mm})\end{array}$} & \multicolumn{2}{|c|}{$\begin{array}{c}\text { Iimo } \\
(0,2 \text { a } 0,002 \mathrm{~mm})\end{array}$} \\
\hline & Real & A parente & & Gmido & Séco & Pêso & Volume & Pêลo & Volume \\
\hline & & & $\%$ & & & $\%$ & $\%$ & $\%$ & $\%$ \\
\hline $0-40 \mathrm{~cm} \quad \ldots \ldots \ldots$ & 2,94 & 1,02 & 65,2 & pi 6 & pi 7 & 11,0 & 3,8 & 56,3 & 19,6 \\
\hline $40-80 \mathrm{~cm} \quad \ldots$ & 3,01 & 0,97 & 67,8 & pt 7 & pg 8 & 13,0 & 4,2 & 47,2 & 15,2 \\
\hline $80-150 \mathrm{~cm}$ & 3,03 & 0,98 & 67,7 & pg 7 & $\operatorname{rg} 8$ & 10,4 & 3,2 & 44,9 & 14,0 \\
\hline \multirow{3}{*}{$\begin{array}{l}\text { Camada do solo } \\
\text { (profundidade) }\end{array}$} & \multicolumn{2}{|c|}{$(<\stackrel{\text { Argila }}{0,002 \mathrm{~mm}})$} & \multirow{2}{*}{$\begin{array}{l}\text { Indice } \\
\text { intern. } \\
\text { (Buiten- } \\
\text { zorg) }\end{array}$} & \multicolumn{2}{|c|}{$\begin{array}{l}\text { Umidade de } \\
\text { murchamento }\end{array}$} & \multicolumn{2}{|c|}{$\begin{array}{l}\text { Umidade equi- } \\
\text { valente }\end{array}$} & \multicolumn{2}{|c|}{$\begin{array}{l}\text { Agua capilar } \\
\text { máxima }\end{array}$} \\
\hline & Péso & Volume & & Pêso & Volume & Péso & Volume & Pêso & Volurne \\
\hline & $\%$ & $\%$ & & $\%$ & $\%$ & $\%$ & $\%$ & $\%$ & $\%$ \\
\hline $0-40 \mathrm{em} \ldots$ & 32,7 & 11,2 & I. Alg. & 17,8 & 18,1 & 26,2 & 26,7 & 35,0 & $\mathbf{3 5 , 7}$ \\
\hline $40-80 \mathrm{~cm} \ldots$ & 39,8 & 12,5 & B. L. & 17,7 & 17,2 & 26,1 & 25,3 & 37,0 & 35,9 \\
\hline $80-150 \mathrm{~cm}$ & 44,7 & 14,4 & B. J. & 17,9 & 17,5 & 26,3 & 25,8 & 38,0 & 37,2 \\
\hline
\end{tabular}

Topografia -... E, no geral, de topografia regular, entretanto apresenta, em certos pontos do Estado, paredóes abruptos com desníveis até de $200 \mathrm{~m}$. As altitudes oscilam entre 400 e $750 \mathrm{~m}$ acima do nível do mar.

Geologia - Provém êste grande tipo de solo do arenito Bauru-Cretáceo (Estampas 8- $B$ e 9- $A$ e $B$ ), de deposição flúvio-lacustres. A composição mineralógica do arenito Bauru é essencialmente representada por quartzo. Dentre os minerais acessórios podemos citar : magnetita, ilmenita, granada, rutila, turmalina, piroxênio, calcedônia, opala e limonita. A área dessa formação geológica é bem irregular em contraste com as demais ; sua espessura é de $50 \mathrm{~m}$, aproximadamente. A irregularidade dessa formação é, sobretudo, devida aos vales de erosão formados pelos rios do Peixe, Aguapeí, Tietê e São José dos Dourados.

Vegetação arbórea natural - Guarantã (Esenbeckea leocarpa Engl.), urindiuva (Astronium urundeuva (alb), Engl), peroba) Aspidosperma olivaceum, M. arg.), paudalho (Gallesia gorazema maq.), etc. ; matas essas contendo boa percentagem de madeiras de lei.

Perfil do solo - Esste grande tipo de solo é, no geral, essencialmente arenoso. A matéria orgânica está distribuída nos primeiros $40 \mathrm{~cm}$ de solo. Sua côr é geralmente clara, acinzentada escura ou avermelhada, A matéria 
QUadro 11.-Características físicas do solo do tipo arenito Bauru. Dados, análise mesînica total e fase líquida

\begin{tabular}{|c|c|c|c|c|c|c|c|c|c|}
\hline \multirow{2}{*}{$\begin{array}{l}\text { Camadu do solo } \\
\text { (1neofundidade) }\end{array}$} & \multicolumn{2}{|c|}{ Musaa específica } & \multirow{2}{*}{$\begin{array}{l}\text { Porosi- } \\
\text { dade } \\
\text { natural }\end{array}$} & \multicolumn{2}{|c|}{$\begin{array}{l}\text { Côr do solo } \\
\text { (Ostwald) }\end{array}$} & \multicolumn{2}{|c|}{$\begin{array}{c}\text { Areia grossa } \\
\text { (2 a } 0,2 \mathrm{~mm})\end{array}$} & \multicolumn{2}{|c|}{$\begin{array}{c}\text { l.imo } \\
(0,2 \text { a } 0,002 \mathrm{~mm})\end{array}$} \\
\hline & Real & Aparente & & Conido & Sèco & Pêso & Volume & Pềo & Volume \\
\hline & & & $\%$ & & & $\%$ & $\%$ & $\%$ & $\%$ \\
\hline $0.40 \mathrm{~cm}$ & 2,63 & 1,34 & 49,0 & pi 4-y is 5 & ng 5 & 62,2 & 31,6 & 30,7 & 15,9 \\
\hline $40-80 \mathrm{~cm}$ & 2,64 & 1,40 & 46,7 & ng 5 & le 5 & 54,1 & 28,5 & 32,5 & 17,5 \\
\hline $80-150 \mathrm{~cm} \quad \ldots$. & 2,65 & 1,41 & 46,6 & le 5 & le 4 & 49,5 & 26,4 & 35,8 & 18,6 \\
\hline \multirow{3}{*}{$\begin{array}{l}\text { ('amada do solo } \\
\text { (profundiclute) }\end{array}$} & \multicolumn{2}{|c|}{$\begin{array}{c}\text { Argila } \\
(<0,002 \mathrm{~mm})\end{array}$} & \multirow{2}{*}{$\begin{array}{c}\text { Indice } \\
\text { intern. } \\
\text { (Buiten- } \\
\text { zorg) }\end{array}$} & \multicolumn{2}{|c|}{$\begin{array}{l}\text { Unidade de } \\
\text { murchamerto }\end{array}$} & \multicolumn{2}{|c|}{$\begin{array}{l}\text { Umidade equi- } \\
\text { valeute }\end{array}$} & \multicolumn{2}{|c|}{$\underset{\text { mŕximıa }}{\text { Amua capilar }}$} \\
\hline & Pêso & Volume & & Péso & Volume & Pêso & Volume & Péso & Volume \\
\hline & $\%$ & $\%$ & & $\%$ & $\%$ & $\%$ & $\%$ & $\%$ & $\%$ \\
\hline $0-40 \mathrm{~cm} \quad \ldots$ & 7,1 & 3,7 & A. I. & 5,6 & 7,5 & 8,2 & 11,0 & 17,0 & 22,8 \\
\hline $40-80 \mathrm{~cm} \quad \ldots \ldots$ & 13,3 & 7,1 & A. L. & 7,9 & 11,0 & 11.6 & 16,2 & 18,0 & 25,2 \\
\hline $80-150 \mathrm{rm} \ldots \ldots$ & 14,7 & 7,7 & B. A. & 9,9 & 14,0 & 14,6 & 20,6 & 29,0 & 28,2 \\
\hline
\end{tabular}

orgânica e os compostos mais ou menos hidlatados de ferro são os responsáveis pela coloração dêstes solos. Abaixo de $40 \mathrm{~cm}$, o perfil pode apresentar uma camada mais ou menos argilosa, isto é, um horizonte iluvial mais ou menos denso, o qual pode chegar a prejudicar o desenvolvimento profundo das raízes das plantas. A profundidade dêste horizonte pode, entretanto, variar bastante.

A fração argila é essencialmente constituída por caolinita, estando também presente o quartzo, e, em pequena percentagem, um tipo de argila montmorilonítica. Estas observações foram obtidas por espectros radiográficos. Ainda na fração argila encontram-se óxidos mais ou menos hidratados de ferro a de alumínio, variando bastante percentualmente.

E. interessante notar-se a presença do tipo montmorilonítico na "fração argila" dêstes solos. Provàvelmente originaram-se de produtos cineríticos vulcânicos que fazem parte do material de cimentação do arenito BauruCretáceo.

São solos, em geral, profundos e permeáveis; entretanto, casos há em que o arenito quase aflora. (Estampas 8- $B$ e 9- $A$ e $B$ ).

São fàcilmente erosáveis, principalmente quando cultivados com plantas anuais, tais como o algodão (2). Devem sempre ser protegidos, por todos os meios, contra êsses danos. () quadro 11 reproduz alguns dados físicos médios dêsise grande tipo de solo (6). 


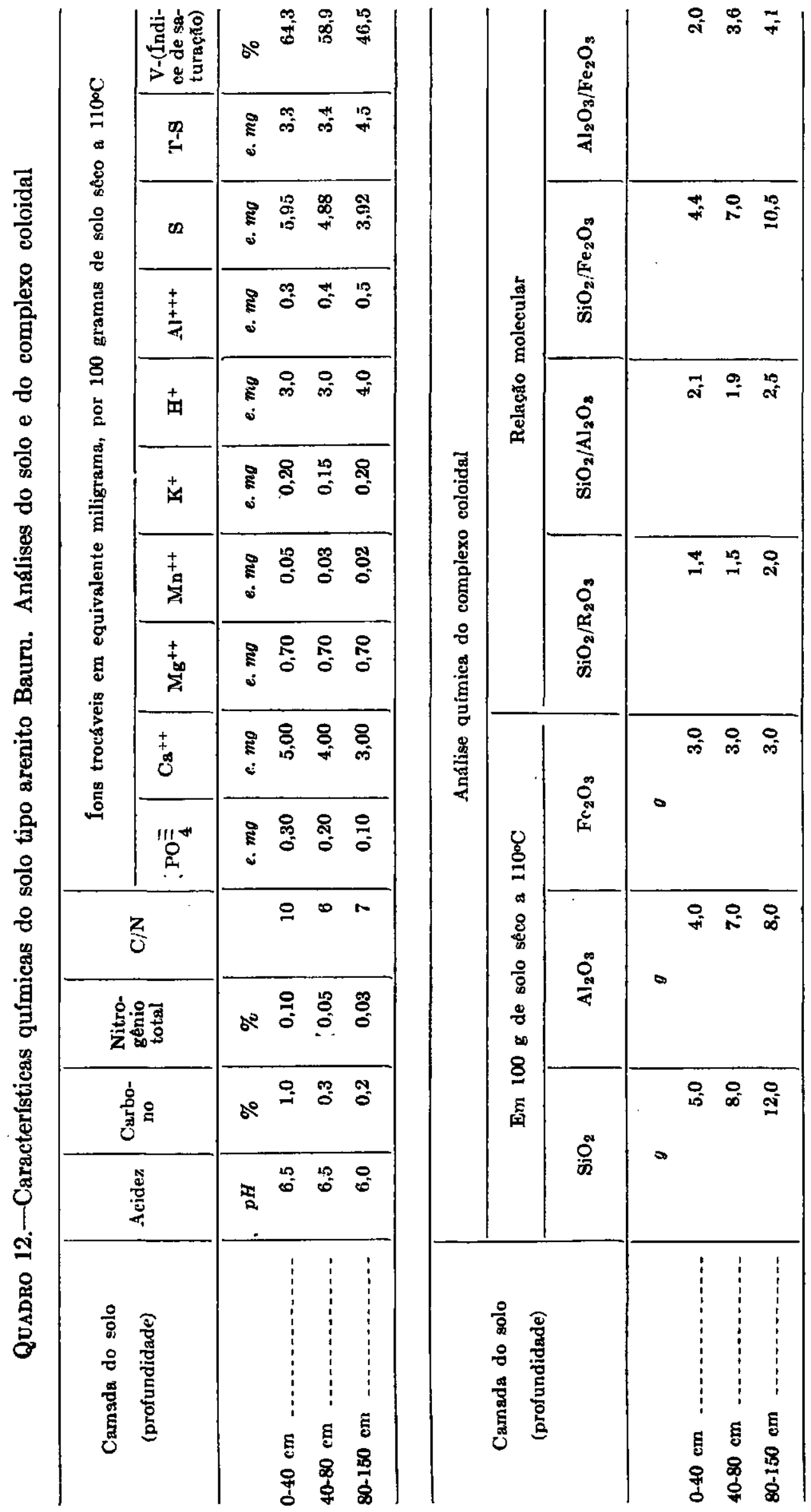


Dados químicos - Quando novos, são regularmente ricos em elementos trocáveis e mesmo no estado potencial.

Hoje em dia, as grandes produções de café e algodão do Estado de São Paulo, provêm dêsses solos. São, contudo, considerados solos de fertilidade efêmera, necessitando logo de adubações maciças de matéria orgânica e adubos minerais (quadro 12).

Culturas principais - Assentam-se nesses solos cêrca de $70 \%$ de nossa cultura cafeeira e cêrca de $80 \%$ de nossa cultura algodoeira, além de boa parte da cultura de arroz (Orysa sativa L.) e milho.

\section{9 - SOLO TERCIÅRIO}

Área - Abrange cêrca de 350.000 hectares, ou seja, $1,4 \%$ da área total do Estado.

Topografia--Solo regularmente ondulado, mostrando, em certas áreas, topografia levemente acidentada. A altitude varia entre 500 e $780 \mathrm{~m}$ acima do nível do mar (Estampa 10-A e $B$ ).

Geologia - Tem êste grande tipo de solo sua origem em folhelhos, argilitos e arenitos da formação geológica terciária (Taubaté). A análise petrográfica mostra escassez em minerais potássicos e cálcicos. A fração argila, proveniente de folhelhos, é de constituição complexa. Estão presentes: caolinita, ilita (ou hidromica ou argila $X$ ) e quartzo. Ainda essa mesma argila possui intensa propriedade tixotrópica. Nesta mesma argila encontram-se pequenos cristais poliédricos amarelo-avermelhados, sendo provàvelmente granadas. $\mathrm{O}$ diâmetro médio dêsses cristais é da ordem de 0,1 a $0,2 \mathrm{~mm}$.

Vegetação natural … Mata regular subhidrófila, de porte médio.

Perfil do solo - São solos que, na maioria das vêzes, mostram coloração amarelada ou avermelhada. Os compostos oxigenados e hidratados de ferro são responsáveis por essa coloração, segundo sua composição mecânica ; tendem para o tipo argiloso; e possuem pequena permeabilidade a água (Estampa 9-A e $B$ ). As diversas constantes químicas e físicas são melhor observadas nos quadros 13 e 14 .

Culturas - Grandes pastagens ; algum café ; milho e diversas outras pequenas culturas.

\section{0 - BAIXADAS}

Área - Foram estudados no Estado de São Paulo cêrca de 450.000 hectares de solo do tipo baixadas.

Este grande tipo, genèricamente denominado baixadas, constitui os solos essencialmente aluvionais e, por conseguinte, bastante heterogêneos. Estão incluídas aí, tôdas as aluviões, sejam desta ou daquela formação geológica. Há, assim, baixadas argilosas ; baixadas ricas em matéria orgâ- 

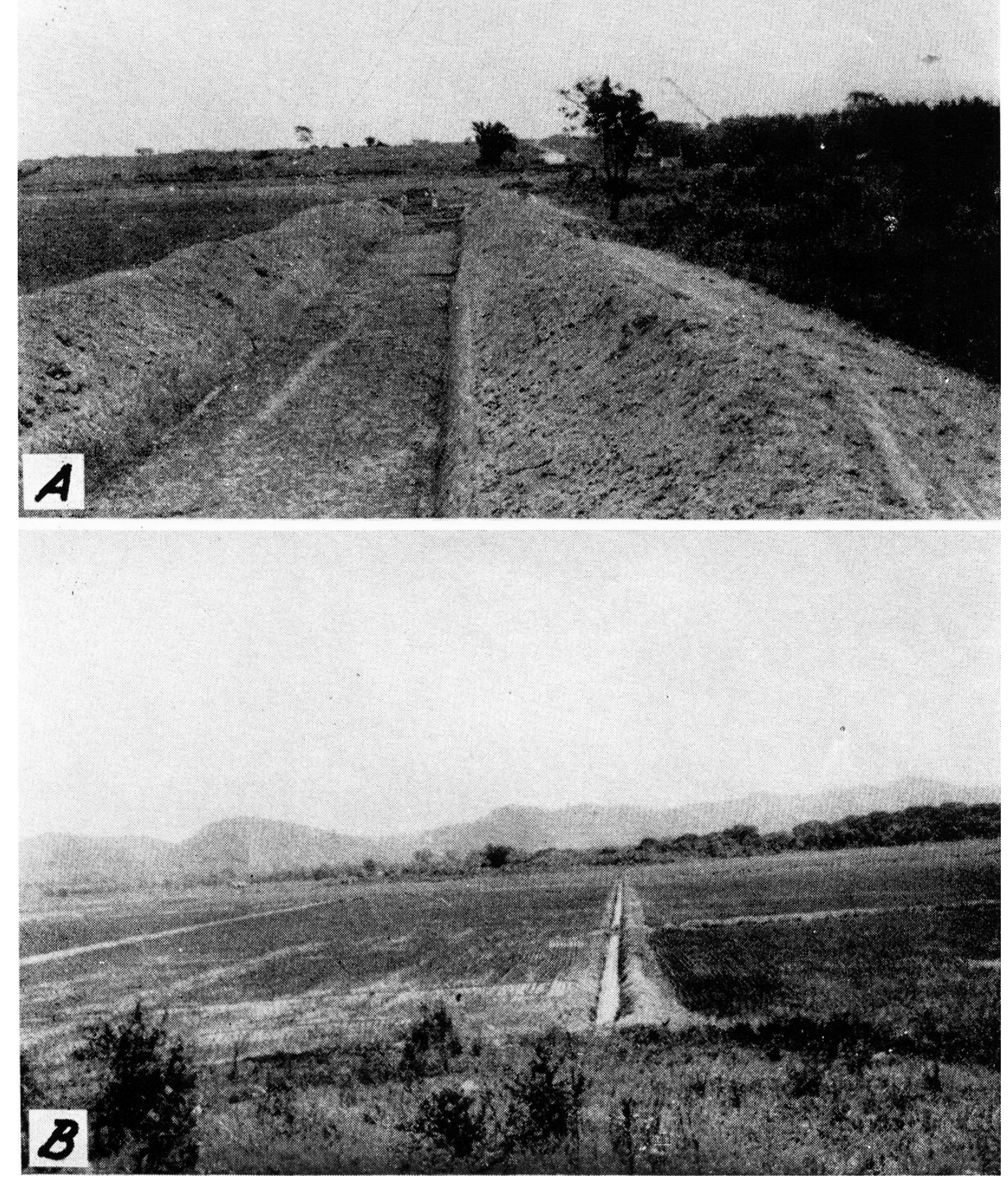

Baixadas. A-Localização: 'Tremembé - Pindamonhangaba (45030' W. (Gr. 22ō̄o' S): altitude: $550 \mathrm{~m}$; canal de irrigação para cultura de arroz. B-Localização; Eugênio de Melo (45045' W. Gr. $23010^{\prime} \mathrm{S}$ ); altitude: $570 \mathrm{~m}$. Várzea do Rio Parába preparada para cultura de arroz. 

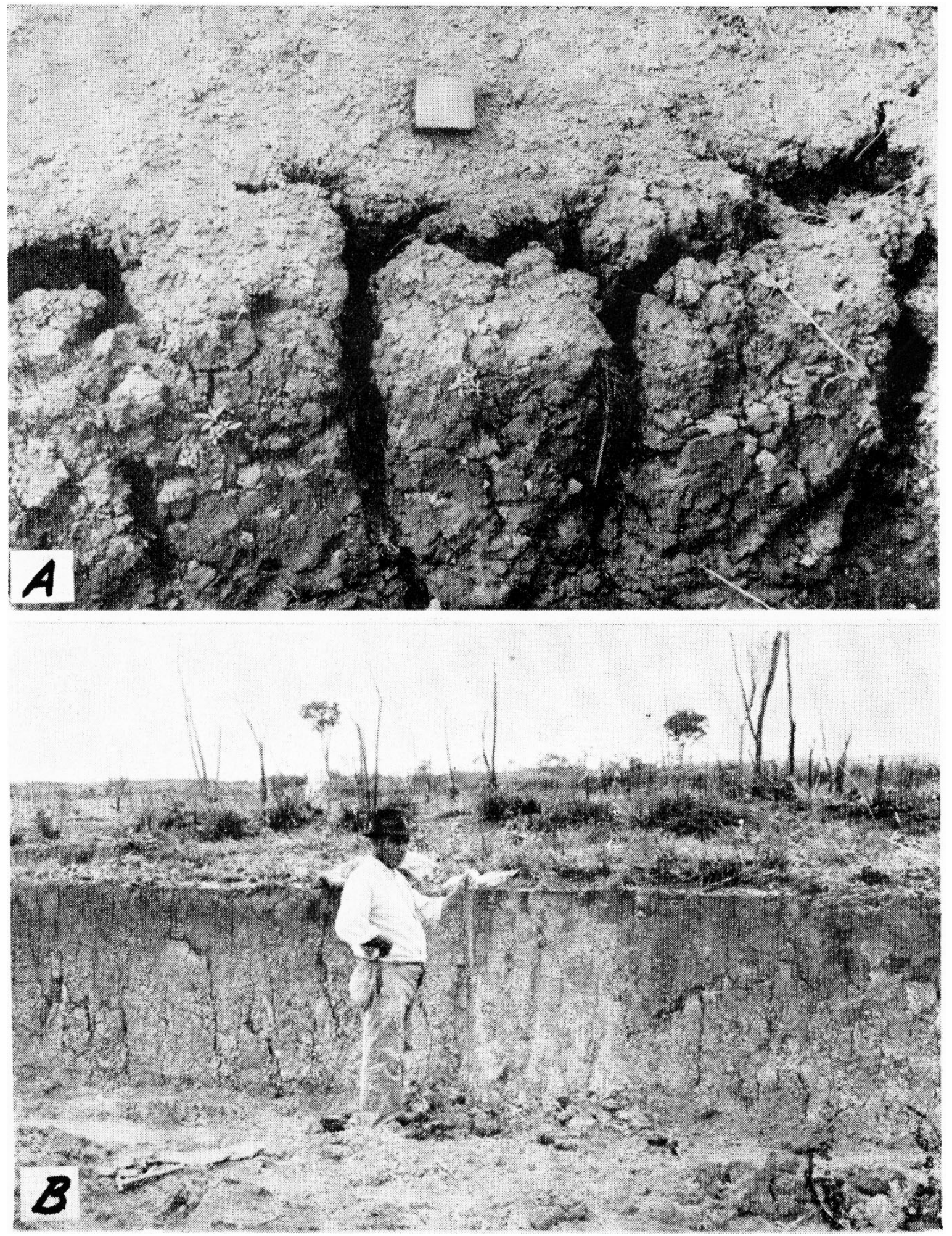

Baixadas. A-Localização: Tremembé - P'intamonlangaba (45̄o30' W. Gr. 22205̄' S); altitude: $550 \mathrm{~m}$. Baixada típica, rica en matéria orgânica bastante mineralizada (cêrca de $38 \%$ ()). Notam-se grandes fendas em virtude do ressecamento do solo. $B$-Vale do Paraíba. Solo argiloso denominado "Taguá", na regiāo; é considerado o melhor solo paru arroz. Altitude: $530 \mathrm{~m}$. Acidez: $\mathrm{pH}=4,6$. Solo rico em potássio. 
QuaDro 13. - Características físicas do solo do tipo Terciário. Dados, análise mecânica total e fase líquida.

\begin{tabular}{|c|c|c|c|c|c|c|c|c|c|}
\hline \multirow{2}{*}{$\begin{array}{l}\text { Camada do solo } \\
\text { (profundidade) }\end{array}$} & \multicolumn{2}{|c|}{ Massa específica } & \multirow{2}{*}{$\begin{array}{c}\text { Porosi- } \\
\text { dade } \\
\text { natural }\end{array}$} & \multicolumn{2}{|c|}{$\begin{array}{l}\text { Côr do solo } \\
\text { (Ostwald) }\end{array}$} & \multicolumn{2}{|c|}{$\begin{array}{c}\text { Areia grossa } \\
(2 \text { a } 0,2 \mathrm{~mm})\end{array}$} & \multicolumn{2}{|c|}{$\underset{\left(0,2 a^{0,002} \mathrm{~mm}\right)}{0, m_{0}}$} \\
\hline & Real & Aparente & & Úmido & Séco & Pêso & Volume & Pêto & Volume \\
\hline & & & $\%$ & & & $\%$ & $\%$ & $\%$ & $\%$ \\
\hline $0-40 \mathrm{~cm}$ & 2,61 & 1,33 & 48,8 & ni 3 & $\ln 3$ & 45,6 & 22,8 & 38,1 & 19.0 \\
\hline $40-80 \mathrm{cs} \quad \ldots$. & 2,62 & 1,32 & 49,8 & il 4 & ge 4 & 38.7 & 19,6 & 35,0 & 14,7 \\
\hline $80-150 \mathrm{cn}$ & 2,64 & 1,28 & 51,8 & le 4 & ic 4 & 34,1 & 16,5 & 32,1 & 14,6 \\
\hline \multirow{2}{*}{$\begin{array}{l}\text { (amada do solo } \\
\text { (profundidade) }\end{array}$} & \multicolumn{2}{|c|}{$(<0,002 \mathrm{~mm})$} & \multirow{2}{*}{$\begin{array}{l}\text { fndice } \\
\text { intern. } \\
\text { (Buiten- } \\
\text { zorg) }\end{array}$} & \multicolumn{2}{|c|}{$\begin{array}{l}\text { Umidade de } \\
\text { murchainento }\end{array}$} & \multicolumn{2}{|c|}{$\begin{array}{l}\text { Umidade equi- } \\
\text { valente }\end{array}$} & \multicolumn{2}{|c|}{$\begin{array}{c}\text { Água capilar } \\
\text { múxima }\end{array}$} \\
\hline & P'êso & Volume & & Pêso & Volume & I'Âso & Volume & P'êṣo & Volume \\
\hline & $\%$ & $\%$ & & $\%$ & $\%$ & $\%$ & $\%$ & $\%$ & $\%$ \\
\hline $0-40 \mathrm{~cm}$ & 16,3 & 8,0 & B. A. & 10,6 & 14,1 & 15,6 & 20,7 & 26,5 & $3 \overline{5}, 2$ \\
\hline $40-80 \mathrm{~cm} \ldots \ldots$ & 26,3 & 12,9 & B. A. & 12,8 & 16,9 & 18,9 & 24,9 & 28,4 & $37, \pi$ \\
\hline $80-150 \mathrm{~cm}$ & 33,5 & 16,0 & $\mathbf{B}$ & 14,7 & 18,8 & 21,6 & 27,6 & 30,4 & 38,9 \\
\hline
\end{tabular}

nica ; algumas, já bastante mineralizadas ; outras, relativamente arenosas, etc.. Como característico único e comum, possuem, exclusivamente, sua formação aluvional. Na figura 3 estão demarcadas as áreas de baixadas importantes (Estampas 11- $A$ e $B ; 12-A$ e $B$ ).

Constituem, no geral, solos férteis, conquanto ainda relativamente pouco explorados entre nós.

Culturas principais - Arroz, batatinha (Solanum tuberosum L.), hortaliças, floricultura e mais lim sem número de outras pequenas culturas.

\section{1 - TERRA ROXA MISTURADA}

Provém êste grande tipo de solo de misturas, em proporçōes várias, entre o tipo arenito Botucatu e o terra roxa legítima.

As suas áreas circunscrevem, no geral, as de terra roxa legítima. Consideramos terra roxa misturada aquêle solo que, pela análise mineralógica, contém entre 10 e $60 \%$ de quartzo, isto é, nas frações : areia grossa (2 a $0,2 \mathrm{~mm})+$ areia fina e limo $(0,2$ a $0,002 \mathrm{~mm})$.

Acima de $60 \%$ de quartzo, nessas frações da análise mecânica, já o solo é classificado como arenito Botucatu. As constantes mineralógicopetrográficas, físicas e químicas da terra roxa misturada, encontram-se, 


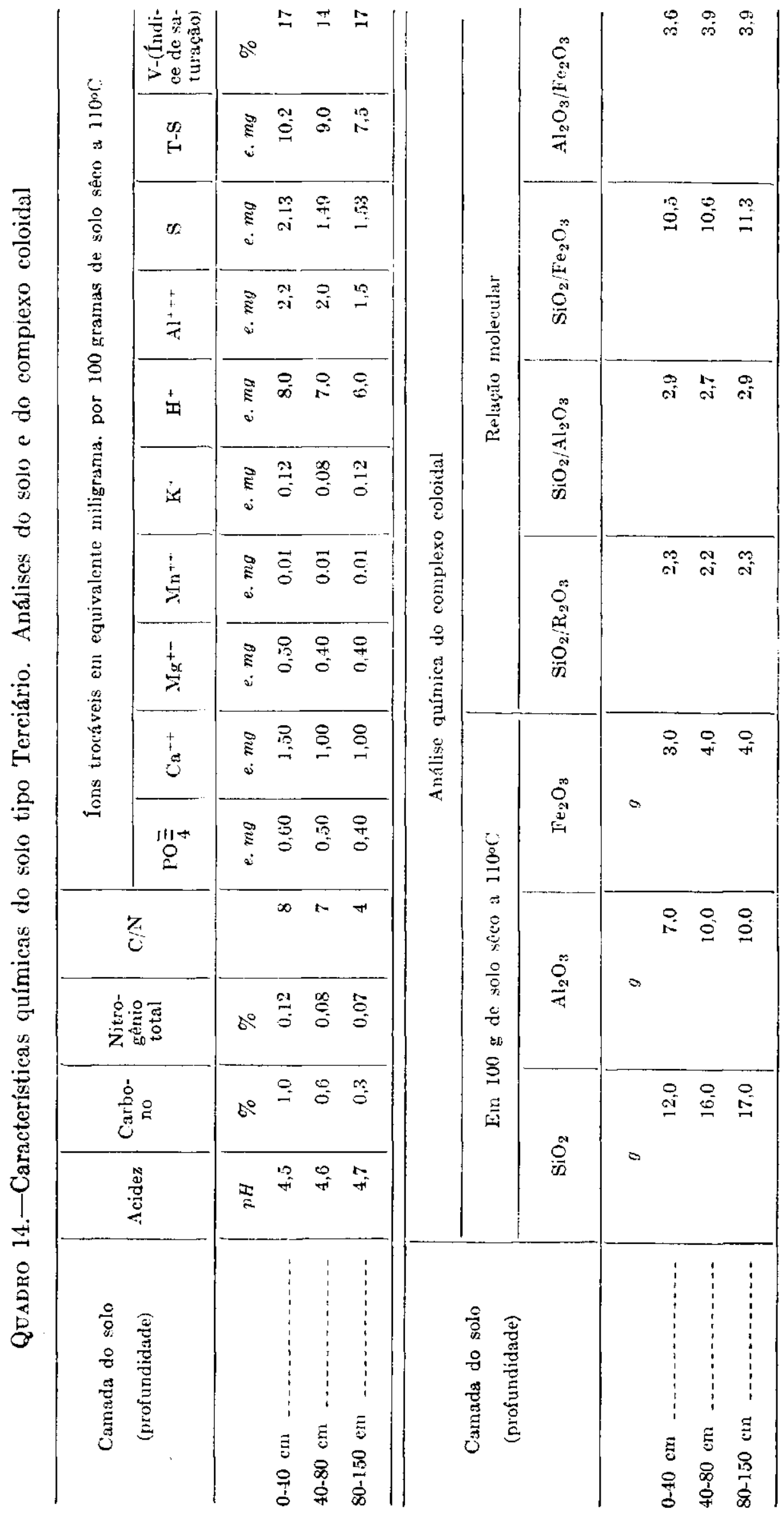




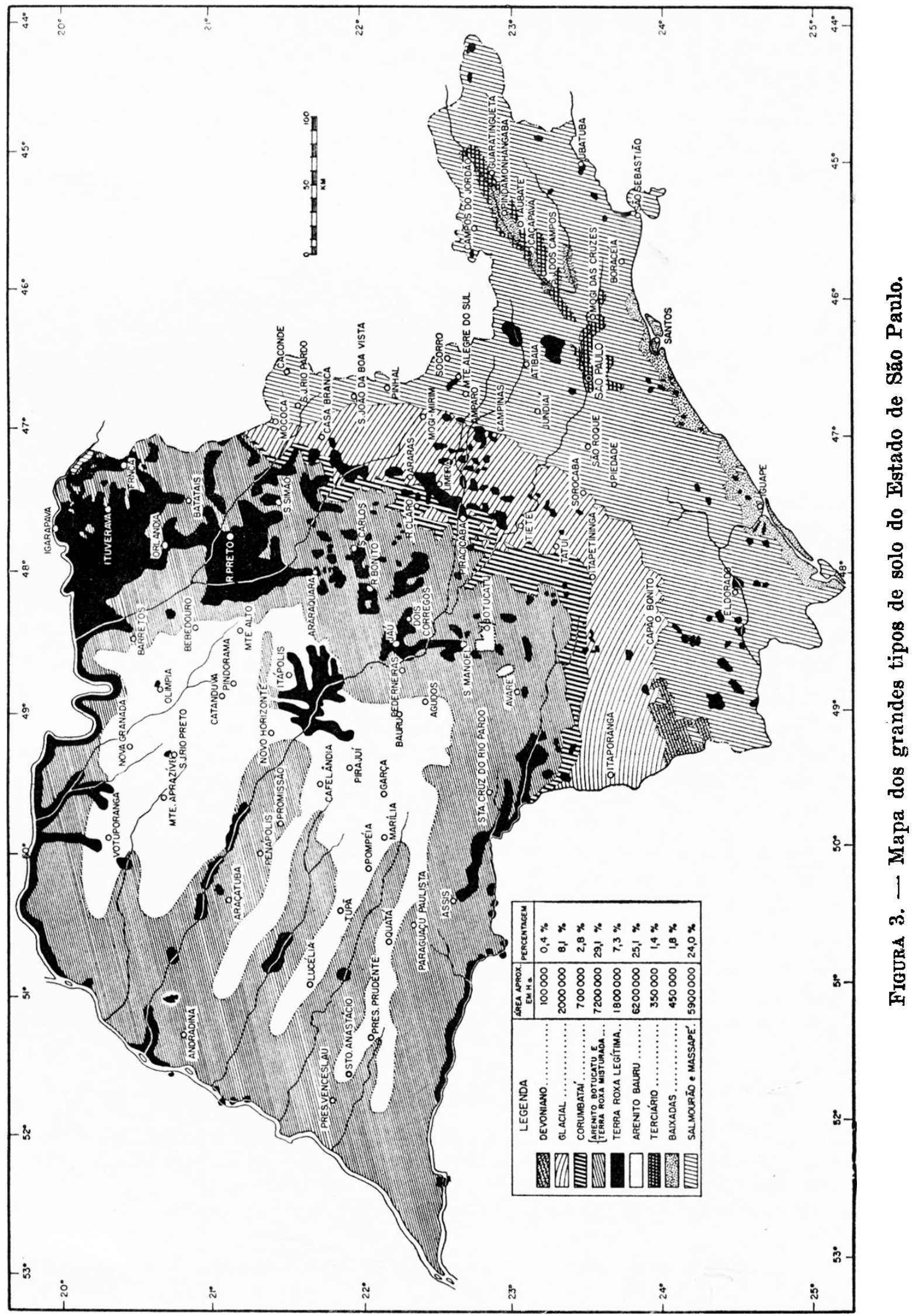


portanto, entre os dois grandes tipos de solo, terra roxa legítima e arenito Botucatu, dependendo da maior ou menor contribuição de um ou de outro tipo.

Podemos estimar a área dêste grande tipo de solo em cêrca de 2.000.000 de hectares. Infelizmente, ainda não é possivel seu mapeamento, motivo pelo qual se encontra na figura 3 , fazendo parte do tipo arenito Botucatu.

\section{RESUMO}

Este trabalho suscinto sôbre os solos do Estado de São Paulo, é o resultado de 15 anos de estudos. Foram feitos nesse espaço de tempo, mais de $80.000 \mathrm{~km}$ de excursões pelo Estado ; coletados cêrca de 700 perfis de solo com suas várias camadas e compreendendo profundidades entre 1,5 e 5,0 m. Foram tomadas mais de 20.000 amostras superficiais (até $40 \mathrm{~cm}$ ) de solo; mais de 4.000 amostras de rochas e cêrca de 6.000 fotografias.

A superfície estudada, envolve cêrca de 24.700 .000 ha e está situada entre as latitudes sul de $19^{\circ} 50^{\prime}$ e $25^{\circ} 10^{\prime}$ e entre as longitudes (seg. Greenwich) de $44^{\circ} 10^{\prime}$ e $53^{\circ} 10^{\prime}$. As altitudes variam entre 3 e $1.700 \mathrm{~m}$ acima do nível do mar.

Neste trabalho básico, inicial, dividimos o Estado em 10 grandes tipos de solo que se acham bastante relacionados com a petrologia em geral. A descrição dêsses 10 grandes tipos, segue a ordem cronológica decrescente, segundo as formações geológicas. Começamos pelos solos provenientes de rochas arcaicas, tais como gnaisses, granitos, etc. Damos, em geral, as características físicas e químicas, assim como geologia e análise mineralógica das fraçōes: areia fina e areia grossa, dêsses grandes tipos de solo.

No trabalho são mencionadas as áreas de cada tipo de solo existente no Estado de São Paulo, as culturas principais e a vegetação nativa. Comentam-se, também ràpidamente, a erodibilidade dêsses solos e as suas características morfológicas. Incluem-se também fotografias típicas dos principais tipos de solo, bem como três mapas, o primeiro mostrando os caminhos principais percorridos nas excursóes; o segundo, os locais de retirada de amostras e o terceiro, o mapa dos 10 grandes tipos de solo do Estado de São Paulo.

\section{S U M M A R Y}

The main soil types of the State of São Paulo, Brazil, were studied during the last 15 years and their general description is presented in this paper. Over $80,000 \mathrm{~km}$ of field excursions were made in order to collect approximately 4,000 rock samples, 700 profiles from depths varying from 1.5 to $5.0 \mathrm{~m}, 20,000$ shallow samples and about 6,000 photographs.

The soil types studiel cover an area of $24,700,000 \mathrm{ha}$, located between the latitudes $19^{\circ} 50^{\prime}$ and $25^{\circ} 10^{\prime}$ South, and the longitudes $44^{\circ} 10^{\prime}$ and $53^{\circ} 10^{\prime}$ West (Greenwich), the altitude varying from $3 \mathrm{~m}$ to $1,700 \mathrm{~m}$ above sea level. For this area the temperature range in the dry winter season (May to July) is from $\mathrm{O}^{\circ}$ to $25^{\circ} \mathrm{C}$ and in the rainy summer months (November to February), from $18^{\circ}$ to $30^{\circ} \mathrm{C}$. The rainfal varies from 2,000 to $3,000 \mathrm{~mm}$ (along the cost) and from 1,000 to $1,800 \mathrm{~mm}$ in the plateau. 
The following ten main soil types were described: massapé salmourão, devoniano, glacial, corumbataí, arenito Botucatú, roxa legitima, arenito Baurí, terciario, baixadas, and roxa misturada, and their locations are given in fig. 3 .

For the ten soil types, determination of physical and chemical properties were made and presented in tables 1 to 14. General information is also given on the specific area, geological origin, topography, native vegetation, and main crops grown in each one of the soils studied.

\section{LITERATURA CITAUA}

1. Catani, R. A. e A. Küpper. As formas "trocável" e fixa dos catíons $\mathrm{K}^{+}, \mathrm{Ca}^{++}$e $\mathrm{Mg}^{++}$ nos solos do Estado de S. Paulo. Bragantia 9 : 185-192. 1949.

2. Grohmann, F. e R. A. Catani. O empobrecimento causado pela erosão e pela cultura algodoeira no solo arenito Bauru. Bragantia 9 : 125-132. 1949.

3. Gutmans, M. Rochas-mater da terra roxa. Bragantia 3 : 271-322. 1943.

4. Paiva Neto, J. E. de. A "fração argila" dos solos do Estado de S. Paulo e seu estudo roentgenográfico. Bragantia 2 : 355-432. 1942.

5. Paiva Neto, J. E. de, R. A. Catani, M. S. Queiroz e A. Küpper. Contribuição ao estudo dos métodos analíticos e de extração para a caracterização química dos solos do Estado de S. Paulo. Rev. Agr. Piracicaba 21 : 417-458. 1946.

6. Paiva Neto, J. E. de e W. De Jorge. Estudo preliminar do sistema água-solo-planta no Estado de S. Paulo. Bragantia $7: 133-150.1947$.

7. Puri, A. N. The ammonium carbonate method of dispersiny soils for mechanical analysis. Soil Sci. 39 : 263-270. 1935. 